Marcin Łysko

\title{
Orzecznictwo karno-administracyjne w zakresie dostaw obowiązkowych płodów rolnych w Polsce Ludowej
}

Keywords: compulsory delivery, petty offences law

\section{Summary}

The compulsory delivery of agriculture products in Poland was introduced in 1951. The Communist government wanted to control agriculture production in this way. The shortages of food in towns caused big political problems and the communists tried to control farmers by the administrative and penal repression. In 1952 boards judging petty offences were established and they punished farmers by fines. They were high, especially for richer farmers "kulaks", but for all groups of farmers they were severe. The efficiency of these fines was not very high, because farmers did not want to pay. Then the authorities introduced an arrest as a substitutive penalty, if the farmer didn't pay the fine. This penalty gave good results - farmers started fulfilling the deliveries, but the system was very repressive. In 1955, when first syndromes of post-Stalin thaw started, the system became less repressive. In 1956 the range of the compulsory delivery was reduced and economic measures were applied to those, who didn't fulfill the duty. They were abolished in 1971.

Wprowadzenie w 1951 r. przez władze Polski Ludowej dostaw obowiązkowych płodów rolnych stanowiło konsekwencję objęcia gospodarki rolnej założeniami planu 6-letniego. Przewidziany na lata 1950-1955 plan sześcioletni ${ }^{1}$ - oprócz nierealnych wskaźników wzrostu produkcji przemysłowej - zakładał

1 Wprowadzony ustawą o 6-letnim planie rozwoju gospodarczego i budowy podstaw socjalizmu na lata $1950-1955$ (Dz. U. Nr 37, poz. 444). 
objęcie rolnictwa zasadami gospodarki planowej drogą jego stopniowej kolektywizacji. Kolektywizacja miała być połączona z likwidacją ostatniego bastionu gospodarki wolnorynkowej w powojennej Polsce, jakim były indywidualne gospodarstwa chłopskie ${ }^{2}$. Polscy komuniści nie posiadali odpowiednio silnej pozycji w społeczeństwie, żeby w zniszczonym przez wojnę kraju zdecydować się na przymusowe przeprowadzenie kolektywizacji w stylu radzieckim. Stąd też obok zakrojonej na szeroką skalę akcji propagandowej wywierali presję ekonomiczną na chłopów przez stopniowe rozszerzanie zakresu ich obowiązków na rzecz państwa, zwłaszcza w postaci świadczeń w naturze 3 . W początkach Polski Ludowej na gospodarstwa indywidualne nałożono obowiązek „wojennych świadczeń rzeczowych"4; kontynuacją świadczeń rzeczowych w warunkach pokoju była instytucja tzw. pomocy sąsiedzkiej w rolnictwie ${ }^{5}$. W połowie $1947 \mathrm{r}$. wprowadzono zaś obowiązek uiszczania części podatku gruntowego w ziemiopłodach ${ }^{6}$, który to obowiązek obciążał większe gospodarstwa do $1951 \mathrm{r}^{7}$

Kulminacja presji ekonomicznej wywieranej na rolników indywidualnych nastąpiła wraz z wprowadzeniem w drugiej połowie 1951 r. dostaw obowiązkowych płodów rolnych. Początkowo ograniczały się one do zboża ${ }^{8}$ i ziemniaków ${ }^{9}$, w 1952 r. zaś objęły także mleko ${ }^{10}$ i zwierzęta rzeźne ${ }^{11}$. Zgodnie z panującą w okresie stalinowskim tendencją do rozwiązywania problemów gospodarczych

2 Akcja przebudowy wsi w duchu socjalistycznym została zapoczątkowana po 1948 r., kiedy zlikwidowano „odchylenie prawicowo-nacjonalistyczne” w szeregach partii. Usunięto z niej zwolenników polskiej drogi do socjalizmu na czele z W. Gomułką, którzy sprzeciwiali się kolektywizacji rolnictwa. J. Kaliński, Gospodarka Polski w latach 1944-1989. Przemiany strukturalne, Warszawa 1995, s. 64.

3 A. Machnikowska, Polityka finansowa wobec rolnictwa w Polsce Ludowej, [w:] Podstawy materialne Państwa. Zagadnienia prawno-historyczne, red. D. Bogacz, M. Tkaczuk, Szczecin 2006, s. 560.

4 Dekret Polskiego Komitetu Wyzwolenia Narodowego z dnia 18 sierpnia 1944 r. o wojennych świadczeniach rzeczowych - obowiązkowych dostawach zbóż i ziemniaków dla państwa (Dz. U. 1944 $\mathrm{Nr} 3$, poz. 9) oraz dekret PKWN z dnia 22 sierpnia 1944 r. o wojennych świadczeniach rzeczowych obowiązkowych dostawach mięsa, mleka i siana dla państwa (Dz. U. 1944 Nr 3, poz. 10). Dekrety obowiązywały do 30 czerwca $1945 \mathrm{r}$.

${ }^{5}$ Dekret z 12 września 1947 r. o pomocy sąsiedzkiej w rolnictwie (Dz. U. Nr 59, poz. 320).

${ }^{6}$ Na podstawie art. 11 ustawy z dnia 3 czerwca $1947 \mathrm{r}$. o nadzorze nad wymiarem i poborem podatku gruntowego (Dz. U. Nr 43, poz. 224) Rada Ministrów wydała w dniu 9 lipca 1947 r. rozporządzenie o obowiązku uiszczania przez niektóre gospodarstwa rolne podatku gruntowego $\mathrm{w}$ ziemiopłodach (Dz. U. Nr 43, poz. 296). Obowiązek ten podtrzymywano corocznie do 1950 r. A. Witkowski, Petnomocnicy do spraw podatku gruntowego w Polsce (1947-1950), Warszawa 2009, s. 312.

7 Podatek gruntowy regulowany dekretem z 20 marca 1946 r. o podatkach komunalnych (Dz. U. Nr 19, poz. 128) został zastąpiony ustawą z dnia 26 lutego 1951 r. o podatkach terenowych (Dz. U. $\mathrm{Nr}$ 14, poz. 110).

8 Dekret z 23 lipca 1951 r. o planowym skupie zbóż (Dz. U. Nr 30, poz. 297) został zastąpiony ustawą z 10 lipca 1952 r. o dostawach obowiązkowych zbóż (Dz. U. Nr 32, poz. 214).

9 Dekret z 8 października 1951 r. o zabezpieczeniu dostaw ziemniaków ze zbiorów 1951 r. (Dz. U. $\mathrm{Nr} 52$, poz. 368) został zastąpiony dekretem z 28 sierpnia 1952 r. o obowiązkowych dostawach ziemniaków (Dz. U. Nr 37, poz. 255).

${ }^{10}$ Dekret z 24 kwietnia 1952 r. o obowiązkowych dostawach mleka (Dz. U. Nr 22, poz. 142).

11 Ustawa z 15 lutego 1952 r. o obowiązkowych dostawach zwierząt rzeźnych (Dz. U. Nr 8, poz. 46). 
za pomocą przymusu, przewidziano surowe sankcje za niewykonanie obowiązków wobec państwa. Kary aresztu lub wiezienia ${ }^{12}$ mogły być wymierzone w postępowaniu sądowym za złośliwe, czyli wielokrotne uchylanie się od obowiązku dostaw $^{13}$. Z kolei jednostkowy czyn, polegający na niewykonaniu dostawy w wyznaczonym terminie, zagrożony był grzywną orzekaną w trybie karno-administracyjnym.

Wydane w drugiej połowie $1951 \mathrm{r}$. dekrety o dostawach obowiązkowych zbóż i ziemniaków przewidywały karę grzywny w wysokości do 3000 złotych, czyli górnej granicy tej kary określonej przez pochodzące z czasów II Rzeczypospolitej Prawo o wykroczeniach ${ }^{14}$.

\section{Podstawowe założenia orzecznictwa karno-administracyjnego Polski Ludowej}

Obowiązywanie przedwojennego prawa o wykroczeniach w Polsce Ludowej wynikało z przejęcia przez komunistów dorobku II Rzeczypospolitej w zakresie prawa sądowego i karno-administracyjnego. Przedwojenny model orzecznictwa w sprawach o wykroczenia opierał się na rozporządzeniu Prezydenta RP z 22 marca 1928 r. o postępowaniu karno-administracyjnym ${ }^{15}$. Rozporządzenie przekazywało do kompetencji organów administracji ogólnej szczebla powiatowego orzekanie w sprawach o wykroczenia zagrożone karą nie wyższą niż 3000 złotych grzywny lub aresztem do 3 miesięcy. Jurysdykcję wykonywał i sprawował jednoosobowo starosta jako „powiatowa władza administracji ogólnej”, jednak w praktyce starostę zastępował zawodowy urzędnik - referent karno-administracyjny. Kara administracyjna stawała się prawomocna i mogła być wykonana pod warunkiem nieskorzystania przez ukaranego z możliwości przekazania sprawy sądowi, co podkreślało zastępczy charakter orzecznictwa karno-administracyjnego ${ }^{16}$. Polskie rozwiązania cechowało przyznanie organom administracyjnym wyłączności karania w sprawach o wykroczenia w I instancji, co argumentowano względami celowości, a zwłaszcza prostoty i szybkości postępowania admi-

${ }^{12}$ Art. 23 dekretu o planowym skupie zbóż stanowił, że „kto złośliwie uchyla się od ciążącego na nim obowiązku sprzedaży zbóż w ramach planu, utrudnia lub udaremnia wykonanie tego obowiązku przez inne osoby, albo publicznie nawołuje do uchylania się od tego obowiązku - podlega karze więzienia do lat 3 lub aresztu".

${ }^{13}$ P. Fiedorczyk, Komisja Specjalna do Walki z Nadużyciami i Szkodnictwem Gospodarczym, Białystok 2002, s. 139.

${ }^{14}$ Rozporządzenie Prezydenta Rzeczypospolitej Polskiej z dnia 11 lipca 1932 r. - Prawo o wykroczeniach (Dz. U. Nr 60, poz. 572).

${ }^{15}$ Dz. U. Nr 75, poz. 444.

${ }^{16}$ W. F. Dąbrowski, Zagadnienia ogólne orzecznictwa karno-administracyjnego, Poznań 1970, s. $22-23$. 
nistracyjnego ${ }^{17}$. Przedwojenny system orzecznictwa karno-administracyjnego sprawdził się w praktyce, gdyż dając administracji możliwość szybkiej reakcji na popełnione wykroczenia, wymagał od niej ścisłego przestrzegania prawa pod sankcją skierowania sprawy na drogę postępowania sądowego ${ }^{18}$.

Wprawdzie przedwojenny model orzecznictwa karno-administracyjnego funkcjonował do kwietnia $1952 \mathrm{r}^{19}$, lecz już pod koniec lat czterdziestych została przesądzona kwestia jego likwidacji. Objęcie władzy przez ekipę B. Bieruta oznaczało podjęcie programu budowy socjalizmu w Polsce na wzór radziecki $\mathrm{w}$ drodze gruntownych przemian politycznych, gospodarczych i społecznych. Aktywną rolę w tym procesie miała odgrywać administracja państwowa, której powierzono zadanie kształtowania stosunków społecznych oraz gospodarczych w duchu socjalistycznym. Przeprowadzona w marcu 1950 r. zgodnie z zasadą tzw. centralizmu demokratycznego reforma administracji terenowej stworzyła jednolity system oparty na ściśle powiązanych ze sobą w ramach tendencji centralizacyjnych radach narodowych ${ }^{20}$. Występujące na szczeblach od gminnego do wojewódzkiego rady narodowe pełniły rolę zarówno organów władzy państwowej w terenie, jak też administracji ogólnej oraz zespolonej z ogólną. Organami wykonawczymi były wybierane przez rady prezydia, którym powierzono m.in. wykonywanie orzecznictwa karno-administracyjnego w I instancji w miejsce zlikwidowanych starostw powiatowych i zarządów miejskich. W praktyce sprawy o wykroczenia rozpoznawał nadal jednoosobowo pracownik prezydium - referent karno-administracyjny ${ }^{21}$.

Prezydia rad narodowych przejęły także zadania dotychczas wykonywane przez organy administracji specjalnej resortu finansów w zakresie realizacji świadczeń pieniężnych na rzecz państwa oraz egzekucji orzeczonych grzywien. Na barkach prezydiów spoczywał zatem ciężar egzekwowania kar grzywny orzekanych w sprawach o niewykonywanie dostaw obowiązkowych. Zakres działania prezydiów rad narodowych nie obejmował natomiast administracji w zakresie dostaw obowiązkowych, które to zadania pełniły usytuowane poza systemem rad narodowych terenowe organy Centralnego Urzędu Skupu i Kontraktacji (CUSiK). W 1954 r. urząd ten przekształci się w Ministerstwo Skupu. Reforma terenowego aparatu administracji przesądziła o likwidacji przedwojennego

${ }^{17}$ M. Zimmermann, Zagadnienia kodyfikacji Prawa i Postępowania karno-administracyjnego, notatka z 1962 r., Archiwum Akt Nowych, Zespół akt Ministerstwa Sprawiedliwości, sygn. teczki 2010, s. 100 (AAN Min. Spr. 2010, s. 100).

${ }^{18}$ M. Zimmermann, Orzecznictwo karno-administracyjne, „Zagadnienia Karno-Administracyjne” (dalej: ZKA) 1965, nr 4, s. 6.

${ }^{19}$ Wprowadzająca socjalistyczny model orzecznictwa ustawa z dnia 15 grudnia 1951 r. o orzecznictwie karno-administracyjnym (Dz. U. Nr 66, poz. 454) weszła w życie 1 kwietnia 1952 r.

${ }^{20}$ Reformy dokonano ustawą z dnia 20 marca 1950 r. o terenowych organach jednolitej władzy państwowej (Dz. U. Nr 14, poz. 30).

${ }^{21}$ J. Jakubowska-Hara, Grzywna w prawie wykroczeń, Warszawa 2004, s. 35-26. 
modelu orzecznictwa karno-administracyjnego, gdyż modelowi temu zarzucano „ścisły związek z ustrojem gospodarki liberalnej, który wymagał sprowadzenia administracji do roli stróża porządku publicznego"22. Zdaniem komunistów, orzecznictwo karno-administracyjne miało aktywnie współdziałać z terenową administracją państwową w procesie organizowania życia społecznego i gospodarczego, w tym zaspokojenia podstawowych potrzeb obywateli. Praktyczna jego realizacja nastąpiła wraz z uchwaleniem 15 grudnia 1951 r. ustawy ${ }^{23}$ (ustawa z 15 grudnia 1951 r.) gruntownie reformującej orzecznictwo karno-administracyjne w duchu socjalistycznym. Filarami nowej koncepcji tego orzecznictwa były zasada kolegialnego orzekania w sprawach o wykroczenia oraz połączenie stosowania środków karnych z metodą przekonywania i społecznego oddziaływania ${ }^{24}$.

Orzecznictwo karno-administracyjne powierzono kolegiom przy prezydiach rad narodowych, począwszy od szczebla gromadzkiego do wojewódzkiego. Członkowie kolegiów byli wybierani przez rady narodowe spośród kandydatów przedstawionych przez organizacje społeczne, czyli w praktyce partię rządzącą. Postępowanie przed kolegiami było dwuinstancyjne. Odwołanie do kolegium wyższego stopnia wprowadzono w miejsce dotychczasowego żądania skierowania sprawy na drogę sądową ${ }^{25}$, pogarszając drastycznie sytuację ukaranego

Wychowawczą koncepcję orzecznictwa karno-administracyjnego najpełniej miał oddawać system kar, którym nadano „charakter odpowiadający roli represji w państwie budującym socjalizm"26. Węzłowym ogniwem reformy był zakaz orzekania aresztu, zarówno jako kary zasadniczej, jak też kary zastępczej na wypadek nieuiszczenia grzywny. W miejsce aresztu wprowadzono karę pracy poprawczej $^{27}$, która była również orzekana jako kara zastępcza w razie stwierdzenia nieściągalności orzeczonych grzywien. Kolegia zostały również upoważnione do stosowania upomnienia zamiast kary, jeżeli ich zdaniem szkodliwość społeczna czynu była niewielka ${ }^{28}$. Z dotychczasowych kar utrzymano grzywnę, która $\mathrm{w}$ przeciwieństwie do pozostałych kar administracyjnych nie posiadała charakteru wychowawczego, lecz miała na celu wyrządzenie ukaranemu dolegliwości materialnej ${ }^{29}$. Maksymalna wysokość grzywny orzekanej w postępowaniu kar-

${ }^{22}$ W. F. Dąbrowski, Zagadnienia ogólne orzecznictwa karno-administracyjnego w PRL, Poznań 1970, s. 45 .

${ }^{23}$ Ustawa z dnia 15 grudnia 1951 r. o orzecznictwie karno-administracyjnym (Dz. U. Nr 66, poz. 454).

${ }^{24}$ O realizację orzeczeń kolegiów karno-administracyjnych, „Poradnik dla Kolegiów Orzekających" 1956, nr 2, s. 3.

${ }^{25}$ M. Jaroszyński, M. Zimmermann, W. Brzeziński, Polskie prawo administracyjne, Warszawa 1956, s. 420 .

${ }^{26}$ R. Rajkowski, Prawo karno-administracyjne Polski Ludowej, Warszawa 1955, s. 85.

${ }^{27}$ Patrz M. Łysko, Kara pracy poprawczej w orzecznictwie karno-administracyjnym Polski Ludowej, „Miscellanea Historico-Iuridica”, t. VI, Białystok 2008.

${ }^{28}$ M. Zimmermann, Orzecznictwo karno-administracyjne, ZKA 1965, nr 4, s. 9.

${ }^{29}$ A. Gubiński, Kary zasadnicze w projekcie prawa o wykroczeniach, ZKA 1969, nr 2, s. 32. 
no-administracyjnym wynosiła 3000 złotych, z tym że kolegia szczebla niższego niż powiatowy mogły wymierzać tę karę w granicach do 300 złotych $^{30}$.

\section{Założenia polityki karno-administracyjnej w sprawach o dostawy obowiązkowe}

Wejście w życie ustawy z 15 grudnia 1951 r. zbiegło się w czasie z rozszerzeniem systemu dostaw obowiązkowych na mleko i żywiec. Ponownie uregulowano, tym razem w aktach rangi ustawowej, problematykę dostaw zboża i ziemniaków. Podobnie jak wcześniejsze dekrety ustawy z 1952 r. przewidywały karę grzywny do 3000 złotych orzekaną w trybie postępowania karno-administracyjnego. Zagrożenie najsurowszą z kar daje świadectwo represyjności orzecznictwa w sprawach o niewykonanie dostaw obowiązkowych, gdyż oprócz grzywny nie przewidziano innych środków karnych. Polityczno-gospodarcze znaczenie dostaw obowiązkowych skutkowało rezygnacją ze stosowania środków wychowawczych, zwłaszcza nagłaśnianej dla celów propagandowych kary pracy poprawczej. Lansowana $\mathrm{w}$ okresie stalinowskim teoria praworządności ludowej, w ramach której eksponowano sumienne wykonywanie przez obywateli obowiązków na rzecz państwa ${ }^{31}$, nakazywała traktować wszelkie przypadki niewykonania dostaw obowiązkowych w kategoriach łamania zasad tej praworządności. Dostawy obowiązkowe miały stanowić „ważne ogniwo w systemie umacniania spójni między miastem i wsią” oraz służyć „wypieraniu elementów spekulacyjnych i kułackich"32 przez zmuszenie ich do wykonywania zobowiązań wobec państwa ${ }^{33}$.

Przekonywanie chłopów do wyrównania zaległości w dostawach miało postać przymusu natury ekonomicznej, czego wyrazem była kara grzywny niezawierająca w sobie elementów oddziaływania wychowawczego. Kara ta miała być stosowana wobec sprawców, którzy zdaniem kolegiów nie rokowali nadziei na to, że środki o charakterze wychowawczym zdołają ich wdrożyć do przestrzegania porządku prawnego. Zalegających z dostawami chłopów traktowano z założenia jako „osobników opornych”, uzasadniając odejście od wychowawczej koncepcji kary administracyjnej w sprawach o dostawy obowiązkowe potrzebą stosowania przymusu w prowadzonej przez „Państwo Ludowe” walce klasowej ${ }^{34}$. Pozbawio-

\footnotetext{
${ }^{30}$ Stanowił o tym art. 8 ustawy z 15 grudnia $1951 \mathrm{r}$.

${ }^{31}$ Według H. Minca: „Ludowa praworządność polega na tym, żeby robotnicy produkowali, aby żołnierze Polski bronili, aby chłopi ją żywili”. Przyczyny obecnych trudności w zaopatrzeniu i środki walki z tymi trudnościami, „Nowe Drogi” 1951, nr 4, s. 23.

${ }^{32}$ Prawo administracyjne, praca zbiorowa pod redakcją M. Jaroszyńskiego, cz. III, Warszawa 1952, s. 131.

${ }^{33}$ H. Minc, Przyczyny obecnych trudności..., s. 23.

${ }^{34}$ O pracy kolegiów orzekających $w$ postępowaniu karno-administracyjnym, Polskie Wydawnictwa Gospodarcze, Warszawa 1952, s 34 .
} 
na akcentów natury wychowawczej kara grzywny miała być stosowana $\mathrm{z}$ „z całą bezwzględnością wobec wroga klasowego, stanowiąc «mocny oręż walki klasowej»" ${ }^{35}$. Towarzysząca akcji dostaw obowiązkowych otoczka ideologiczna odcisnęła swoje piętno na polityce karnej kolegiów, które orzekając grzywny wobec zalegających z dostawami chłopów miały pamiętać „o klasowym charakterze kary, która winna być stosowana tam, gdzie obserwujemy zwiększoną aktywność wroga klasowego"36. Określone postanowieniami ustawy z 15 grudnia $1951 \mathrm{r}$. zasady wymiaru kary względem chłopów zalegających z dostawami były zatem stosowane przez kolegia w duchu „walki klasowej”. Przy wymierzaniu kar ustawodawca nakazywał uwzględniać w pierwszym rzędzie szkodliwość społeczną czynu, interpretowaną jako „szkodę wyrządzoną interesom mas pracujących Polski Ludowej”. Szkoda ta miała przejawiać się zwłaszcza w „niewykonywaniu obywatelskich obowiązków wobec Państwa”, co z góry przesądzało kwalifikowanie przypadków zalegania $\mathrm{z}$ dostawami obowiązkowymi jako czynów społecznie szkodliwych. Ocena stopnia szkodliwości tego rodzaju wykroczeń miała być dokonywana $\mathrm{w}$ duchu „dużego uświadomienia społecznego i politycznego oraz zrozumienia dla toczącej się w Polsce Ludowej walki klasowej"37.

Zgodnie z postanowieniami ustawy z 15 grudnia $1951 \mathrm{r}$. kolegia powinny także zwracać uwagę na czynniki związane bezpośrednio ze sprawcą wykroczenia, takie jak stopień zawinienia oraz warunki społeczne, osobiste i materialne. W praktyce największą wagę przykładano do tego, „czy obwiniony prowadzi uczciwe życie człowieka pracy" oraz jego postawy w pracy i udziału w życiu społecznym. W przypadku dostaw obowiązkowych oznaczało to skierowanie ostrza represji karno-administracyjnej przeciwko warstwie „bogaczy wiejskich”, z założenia traktowanych przez władze jako element aspołeczny, naruszający swoją postawą zasady współżycia w społeczeństwie socjalistycznym. Wydane w $1952 \mathrm{r}$. materiały szkoleniowe dla kolegiów zalecały karanie „bogacza wiejskiego” z całą surowością prawa, jeżeli „nie wywiązuje się on ze swoich obowiązków na rzecz państwa, jeżeli narusza ustawy, jeżeli z jego czynu przebija wrogie ustosunkowanie się do obecnej rzeczywistości” ${ }^{38}$. Odmiennie kolegia miały traktować chłopów małorolnych, gdyż wspomniane materiały szkoleniowe mówiły wprost, że „inaczej należy na wsi osądzać chłopa małorolnego a kułaka”. Niewykonanie dostaw przez chłopa małorolnego powinno być przedmiotem wszechstronnej oceny kolegium pod kątem przyczyn powodujących niemożność wywiązania się z obowiązku dostaw. Należało także ustalić czy niewykonanie dostaw było spowodowane brakiem dostatecznej świadomości klasowej chłopa małorolnego.

${ }^{35}$ O stosowaniu kar w postępowaniu karno-administracyjnym, Polskie Wydawnictwa Gospodarcze, Warszawa 1952, s. 3.

${ }^{36}$ O pracy kolegiów..., s. 34 .

${ }^{37}$ Ibidem, s. 35.

${ }^{38} \mathrm{O}$ stosowaniu kar..., s. 4. 
W takiej sytuacji kolegium powinno ograniczyć się do niewysokiej grzywy lub nawet upomnienia, połączonych $\mathrm{z}$ odpowiednim pouczeniem obwinionego ${ }^{39}$. Wobec chłopów małorolnych zalecano zatem łagodzenie represyjności kary administracyjnej przez wprowadzanie elementów oddziaływania wychowawczego $^{40}$. Jednak praktyczna realizacja tego założenia zeszła na dalszy plan wobec presji wywieranej na kolegia w kierunku wzmocnienia dyscypliny wykonania dostaw obowiązkowych.

\section{Początki działalności kolegiów w akcji dostaw obowiązkowych}

$\mathrm{Na}$ gruncie doświadczeń zebranych w pierwszym roku obowiązywania ustawy z 15 grudnia 1951 r. szybko zrezygnowano z kierowania spraw o niewykonanie dostaw obowiązkowych do kolegiów szczebla gminnego, gdyż te były

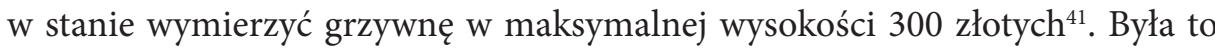
kara na tyle niska przy ówczesnej sile nabywczej pieniądza, że nie robiła większego wrażenia na zalegających $\mathrm{z}$ dostawami rolnikach, którzy woleli zapłacić niewysoką grzywnę niż wykonać zaległe zobowiązania ${ }^{42}$. Orzecznictwo w sprawach o niewykonanie dostaw obowiązkowych przekazano na zasadzie wyłączności kolegiom przy prezydiach powiatowych rad narodowych, ale te często „wykazywały oportunistyczną niechęć do stosowania i wykonywania kar” ${ }^{3}$. „Oportunizm” miał wyrażać się w wymierzaniu niewielkich kar w stosunku do możliwości ekonomicznych zalegającego $\mathrm{z}$ dostawami chłopa ${ }^{44}$.

Próbą przezwyciężenia marazmu polegającego w ocenie władz na prowadzeniu zbyt liberalnej polityki karno-administracyjnej było zalecenie organizowania rozpraw pokazowych, podczas których mieli być przykładnie karani „wybitnie oporni bogaci chłopi”45. Przeprowadzanym w poszczególnych gminach rozprawom pokazowym przypisywano ważną rolę polityczno-propagandową, gdyż miały one przekonać chłopów mało- i średniorolnych do sumiennego wykonywania obowiązków na rzecz państwa. Stąd tzw. aktyw gminny starał się zapewnić udział na rozprawach jak największej liczby chłopów, zwłaszcza tych przodujących w wykonywaniu obowiązku dostaw. Przeprowadzanym w miejscach publicznych rozprawom starano się nadać właściwą rangę polityczno-wychowawczą, jak to miało miejsce w gminie Stromiec w powiecie radomskim.

\footnotetext{
${ }^{39}$ Ibidem.

${ }^{40}$ Po wyborach do kolegiów, „Biuletyn dla Członków Kolegiów Karno-Administracyjnych” 1954, nr 1, s. 6 .

${ }^{41}$ Wynikało to z postanowień art. 9 ustawy z 15 grudnia $1951 \mathrm{r}$.

${ }^{42}$ A. Ciszek, Rozprawa pokazowa w gminie Stromiec, „Biuletyn dla Członków Kolegiów Karno-Administracyjnych" 1954, nr 1, s. 21.

${ }^{43}$ Wszystkie sity do walki o wykonanie planu skupu zboża, „Rada Narodowa” 1953, nr 21, s. 4.

${ }^{44}$ A. Ciszek, Rozprawa pokazowa..., s. 21.

${ }^{45}$ Ibidem.
} 
Rozprawa przeciwko chłopom zalegającym z wykonaniem dostaw żywca odbyła się tam w obszernej klasie szkolnej, a „stół przybrano czerwonym suknem”. Specjalnie dobrany „silny skład orzekający” zapoznał się wcześniej z przygotowanymi sprawami, które dotyczyły zaległości w dostawach żywca ze strony kułaków. Sporządzone przez pełnomocników aparatu skupu wnioski o ukaranie zostały dokładnie sprawdzone pod kątem „słuszności klasowej”, skutkiem czego wycofano dwa nietrafne wnioski, „natomiast sporządzono jeszcze 3 nowe wnioski przeciwko wybitnie opornym chłopom, o których było wiadomo, że żywiec posiadają". Podczas przeprowadzonej w obecności mało- i średniorolnych chłopów rozprawy starano się pokazać obwinionym „niesłuszność ich postępowania, lekceważenie przez nich upomnień i rozmów”, wymierzając ostatecznie kary w wysokości od 1500 do 3000 złotych. Zakończona orzeczeniem surowych kar rozprawa pokazowa w gminie Stromiec miała spełnić swoje zadanie, gdyż „kilku obwinionych od razu na rozprawie oświadczyło, że w ciągu kilku dni wykonają obowiązkowe dostawy". Słuszność i skuteczność zapadłych na rozprawie orzeczeń miał potwierdzić fakt, że „już na następnym spędzie wszyscy ukarani zgłosili się z tucznikami, ponadto znacznie wzrosły dostawy żywca i mleka w całej gminie" ${ }^{46}$.

Sprawozdania $\mathrm{z}$ rozpraw pokazowych $\mathrm{w}$ sprawach o niewykonanie dostaw obowiązkowych często gościły na łamach prasy w pierwszej połowie lat pięćdziesiątych, stanowiąc wyraz wszechobecnej w tamtym okresie propagandy. Rzeczywistość wyglądała zgoła odmiennie, gdyż obciążone nawałem pracy kolegia powiatowe nie chciały angażować się w organizację czasochłonnych rozpraw pokazowych, wymagających wysłania w teren najlepszych składów orzekających. Czynnikiem zniechęcającym prezydia rad narodowych do przeprowadzania rozpraw pokazowych była konieczność szczegółowego badania wniosków o ukaranie pod kątem ich trafności klasowej. Referaty karno-administracyjne miały wiele zastrzeżeń do wniosków o ukaranie sporządzanych przez gminnych pełnomocników aparatu skupu, którzy nie radzili sobie z nawałem pracy w okresie największego natężenia dostaw obowiązkowych ${ }^{47}$. Ponieważ poziom wniosków o ukaranie pozostawiał wiele do życzenia, to obowiązkiem kontroli tych wniosków obarczono pracowników prezydiów gminnych i powiatowych rad narodowych, którzy mieli „sprawdzać realność wniosku, przeprowadzić rozmowy z zalegającymi i dopiero wówczas po rozmowie sprawę skierować do kolegium" ${ }^{48}$.

Na prezydia rad narodowych próbowano przerzucić ciężar prowadzenia rozmów wychowawczych z rolnikami niewykonującymi dostaw, przypisując tym

\footnotetext{
${ }^{46}$ Ibidem, s. 21-22.

${ }^{47}$ Ibidem, s. 21.

${ }^{48}$ Kolegia orzekajace $w$ woj. wrocławskim $w$ walce o wykonanie obowiazkowych dostaw, „Rada Narodowa" $1953, \mathrm{nr} 21, \mathrm{~s} .22$.
} 
rozmowom duże znaczenie wychowawcze w odniesieniu do grupy tzw. „pracujących chłopów". Rozmowy wychowawcze miały przekonać tych chłopów do dobrowolnego wykonania zaległych dostaw w myśl zasady, że „sankcje karne stosowane są wobec uchylających się wtedy, gdy metoda przekonywania nie odnosi skutku" ${ }^{49}$. Wobec zalegających z dostawami bogatych chłopów zamiast prowadzenia „intensywnej roboty polityczno-uświadamiającej” miały być stosowane surowe grzywny, „które godzą w spekulantów i kombinatorów niewykonujących obowiązkowych dostaw" ${ }^{\prime 50}$. Towarzysząca akcji dostaw obowiązkowych atmosfera walki klasowej skutkowała wyłączeniem bogatych chłopów z kręgu podmiotów objętych rozmowami wychowawczymi i stosowaniem wobec nich wyłącznie środków o charakterze represyjnym. Wnioski o ukaranie sporządzone przeciwko kułakom były kierowane do kolegiów bez uprzedniego sprawdzenia ich zasadności, gdyż zakres prowadzonej przez prezydia rad narodowych kontroli miał ograniczać się do wniosków przeciwko mało- i średniorolnym chłopom. W praktyce prezydia rad narodowych nie były w stanie sprostać nawet temu zadaniu, co wynikało z akcyjności działania terenowego aparatu administracji państwowej. Dopingowany przez władze do wzmożonego wysiłku celem ratowania zagrożonego planu dostaw, aparat skupu masowo sporządzał wnioski o ukaranie, które bez uprzedniego zbadania okoliczności sprawy kierowano do prezydiów rad narodowych. Przy tak dużym napływie wniosków prezydia nie były w stanie kontrolować ich poprawności ani tym bardziej wzywać obwinionych chłopów na rozmowy wychowawcze.

Największą wagę przykładano do sprawnego przekazania sprawy referatom karno-administracyjnym obsługującym kolegia, preferując zdecydowanie szybkość ukarania kosztem słuszności wydanego orzeczenia. Termin przedawnienia orzekania w sprawach o wykroczenia był dosyć krótki, gdyż wynosił 6 miesięcy od momentu popełnienia czynu. Podobnie długość terminu przedawnienia wykonania kary wynosiła 6 miesięcy od dnia uprawomocnienia orzeczenia kolegium $^{51}$.

Położenie głównego nacisku na szybkość stosowania represji karno-administracyjnej powodowało wydawanie orzeczeń bez uprzedniego zbadania okoliczności sprawy, a jedynie na podstawie ustaleń zawartych we wnioskach o ukaranie. Przeprowadzane przez sprawującą nadzór nad orzecznictwem karno-administracyjnym prokuraturę $e^{52}$ wyrywkowe kontrole wskazywały na nieprawidłowości w pracy kolegiów spowodowane brakiem dokładnego ustalenia okoliczności sprawy. Szablonowe podejście składów orzekających do wymierza-

\footnotetext{
${ }^{49}$ Ibidem.

${ }^{50}$ Ibidem.

${ }^{51}$ Wynikało to z art. 16 ustawy z 15 grudnia $1951 \mathrm{r}$.

${ }^{52} \mathrm{Na}$ mocy postanowień art. 46 ustawy z 15 grudnia 1951 r. Generalny Prokurator i jego organy sprawowali nadzór nad ścisłym przestrzeganiem prawa w postępowaniu karno-administracyjnym.
} 
nia kar prowadziło do sytuacji, w których skazywano chłopów wbrew okolicznościom sprawy lub wydawano orzeczenia niewspółmierne do szkodliwości społecznej czynu i stopnia zawinienia sprawcy. Taka postawa kolegiów była zdaniem prokuratury tym bardziej naganna, że jej skutki dotykały w dużej mierze chłopów mało- i średniorolnych, którzy z przyczyn obiektywnych nie mogli wykonać dostaw. Miało to prowadzić do wypaczenia koncepcji surowego traktowania kułaków i stosowania względem pozostałych grup ludności wiejskiej łagodnej polityki karnej, połączonej z pracą polityczno-wychowawczą. Tymczasem miały miejsce przypadki wydawania orzeczeń bezzasadnie uniewinniających kułaków lub wymierzania im symbolicznych kar pomimo posiadania możliwości wywiązania się z obowiązku dostaw ${ }^{53}$.

Kierowany pod adresem kolegiów orzekających zarzut niewłaściwego podejścia do „klasowego charakteru” represji karno-administracyjnej nie wpływał $\mathrm{w}$ tak dużym stopniu na planowy przebieg akcji dostaw obowiązkowych, jak powszechnie występujące problemy z wykonawstwem orzeczonych kar grzywny. Wykonanie kar orzeczonych przez kolegia szczebla powiatowego leżało w gestii referatu społeczno-administracyjnego prezydium gminnej rady narodowej właściwej według miejsca zamieszkania ukaranego chłopa. Egzekucję w trybie przepisów dekretu z dnia 28 stycznia 1947 r. o egzekucji administracyjnej świadczeń pieniężnych ${ }^{54}$ mieli przeprowadzać specjalnie w tym celu przewidziani pracownicy, ale prezydia rad narodowych miały poważny problem ze znalezieniem odpowiednich kandydatów na egzekutorów ${ }^{55}$. Problemy z powołaniem egzekutorów skutkowały przekazywaniem kompetencji w zakresie przymusowej realizacji kar grzywny referatom finansowym prezydiów rad narodowych. Jednakże referaty finansowe nie były w stanie sprostać dodatkowemu obciążeniu, jakim było ściąganie orzeczonych w postępowaniu karno-administracyjnym kar grzywny. Ich podstawowym obowiązkiem była realizacja świadczeń pieniężnych stanowiących dochód budżetu państwa, w tym obciążającego mieszkańców wsi podatku gruntowego. Traktowanie obciążeń podatkowych wsi w kategoriach instru-

${ }^{53}$ M. Majster, E. Liberman, O niektórych zadaniach prokuratora w zakresie nadzoru nad orzecznictwem karno-administracyjnym, „Biuletyn Generalnej Prokuratury. Artykuły wybrane”, Warszawa 1955, s. 114-115.

${ }^{54}$ Dz. U. Nr 21, poz. 84. Przepisy dekretu uzupełniała Instrukcja Ministerstwa Finansów z dnia 27 sierpnia 1951 r. w sprawie egzekucji należności pieniężnych od rolników; Zadania prokuratury $w$ zakresie sprawowania nadzoru nad postępowaniem i orzecznictwem karno-administracyjnym w sprawach o wykroczenia przeciwko przepisom dekretów o planowym skupie zbóż i zabezpieczeniu dostaw ziemniaków ze zbiorów 1951 r. oraz nad egzekucją należności pieniężnych rolników, „Biuletyn Generalnej Prokuratury" 1951, nr 11, s. 22.

${ }^{55}$ Wskazuje na to pochodząca z 1952 r. informacja o braku egzekutorów w „województwach bydgoskim, olsztyńskim i innych”. Nieliczni pracujący egzekutorzy nie byli w stanie podołać swoim obowiązkom, jak to miało miejsce w powiecie Lubań w województwie wrocławskim, gdzie jeden poborca przypadał na 13 gmin; E. Dornfest, Doświadczenia pierwszego okresu stosowania ustawy o orzecznictwie karno-administracyjnym, „Rada Narodowa” 1952, nr 13, s. 26-27. 
mentu walki klasowej pociągało za sobą praktykę ustalania wysokiego wymiaru podatku gruntowego, zwłaszcza wobec chłopów należących do grupy „bogaczy wiejskich". Ustalanie obciążeń podatkowych w oderwaniu od realnych możliwości ekonomicznych gospodarstw rodziło problemy z egzekucją tych świadczeń. $\mathrm{W}$ ramach czynności egzekucyjnych podlegały zajęciu, a następnie sprzedaży w drodze publicznej licytacji należące do dłużnika ruchomości, przede wszystkim płody rolne i zwierzęta gospodarskie ${ }^{56}$.

\section{Wprowadzenie zastępczej kary aresztu w sprawach o dostawy obowiązkowe}

Podejmowane przez władze w latach 1952-1953 wysiłki w celu pobudzenia aparatu rad narodowych do większego zaangażowania w akcję dostaw obowiązkowych miały charakter doraźnych czynności, podyktowanych potrzebą chwili. Prowadzone na zasadzie „akcyjności” działania powodowały tylko przejściową poprawę stanu wykonania dostaw w poszczególnych gminach i powiatach. Nie były jednak w stanie trwale rozwiązać problemów leżących u podstaw niskiej skuteczności orzecznictwa kolegiów, w tym kluczowego problemu egzekucji kar grzywny. W ocenie władz najważniejszym przejawem „słabości dotychczasowej pracy rad narodowych w dziedzinie skupu" było niewłaściwe funkcjonowanie orzecznictwa karno-administracyjnego. Podkreślano zwłaszcza „oportunistyczną niechęć do stosowania i wykonywania kar" ${ }^{37}$, wskutek czego orzecznictwo kolegiów nie było w stanie zapewnić dyscypliny wykonania dostaw obowiązkowych. Tymczasem narastające od 1951 r. trudności w dziedzinie gospodarki rolnej uczyniły z tych dostaw „węzłowe ogniwo zaopatrzenia miast w żywność” 58 .

Poszukując sposobów przezwyciężenia występujących trudności, poddano krytycznej analizie podstawowe założenie socjalistycznego modelu orzecznictwa karno-administracyjnego, wyrażające się w całkowitej rezygnacji ze stosowania kary aresztu, nawet jako kary zastępczej. Wprowadzona w miejsce aresztu kara pracy poprawczej była pomyślana również jako kara zastępcza w przypadku bezskutecznej egzekucji grzywny ${ }^{59}$. Położenie przez ustawodawcę głównego nacisku na funkcję wychowawczą orzecznictwa karno-administracyjnego zaczęto nieoficjalnie odbierać w kategoriach zagrożenia realizacji postawionych przed admini-

${ }^{56}$ A. Witkowski, Petnomocnicy rzadowi..., s. 317.

${ }^{57}$ E. Dornfest, Doświadczenia pierwszego okresu..., s. 26-27.

${ }^{58}$ A. Gubiński, Ewolucja stosowanych przez kolegia środków karnych i zasad wymiaru kary, „Zagadnienia Wykroczeń" 1977, nr 6, s. 28

${ }_{59}$ Zastępczą karę pracy poprawczej orzekano, przyjmując 1 dzień tej kary jako równowartość grzywny w wymiarze od 10 do 40 złotych. Wymiar kary zastępczej nie mógł przekroczyć jego ustawowego maksimum, czyli 3 miesięcy. J. Jakubowska-Hara, Grzywna..., s. 41. 
stracją zadań ${ }^{60}$. Krytycznej ocenie skuteczności orzecznictwa karno-administracyjnego towarzyszyły postulaty wzmocnienia jego represyjności, gdyż stosowane przez kolegia środki karne nie były w stanie należycie zabezpieczyć planowej realizacji dostaw obowiązkowych ${ }^{61}$. W opinii władz znaczenie dostaw obowiązkowych „dla budownictwa socjalistycznego i realizacji narodowych planów gospodarczych” przemawiało za koniecznością wzmocnienia represji „wobec tych, którzy nie wykonują obowiązków na rzecz państwa" ${ }^{\prime 2}$. Praktyczna realizacja tego postulatu nastąpiła przez wprowadzenie dekretem z 4 marca 1953 r. $^{63}$ zastępczej kary aresztu w sprawach o niewykonanie dostaw obowiązkowych ${ }^{64}$. Wydarzenie to zbiegło się w czasie z wydaniem tzw. dekretów marcowych ${ }^{65}$, przewidujących szczególną ochronę prawno-karną własności społecznej ${ }^{66}$. Władza komunistyczna oficjalnie zaczęła traktować represję karną w kategoriach jednego z głównych środków rozwiązywania problemów gospodarczych, wynikłych w związku z realizacją planu 6-letniego.

Polityczno-ideowy charakter dekretu z 4 marca 1953 r. wyrażał się w oficjalnym traktowaniu zastępczej kary aresztu jako instrumentu walki klasowej. Twierdzono, że kara ta „odgrywa poważną rolę w toczącej się walce klasowej z elementami kułackimi i ich poplecznikami" ${ }^{7}$. Konsekwencją klasowego podejścia do represji karno-administracyjnej był rygorystyczny tryb stosowania zastępczej kary aresztu. Była ona orzekana przez kolegium jednocześnie z wymierzeniem grzywny na wypadek nieuiszczenia tej ostatniej w ciągu siedmiu dni od doręczenia ukaranemu wezwania do zapłaty ${ }^{68}$. Przepisy dekretu z 4 marca 1953 r. nie wymagały wcześniejszego stwierdzenia bezskuteczności egzekucji kary grzywny. Rygorystyczny automatyzm tego rozwiązania wzmacniał fakt zwolnienia kolegium z obowiązku czynienia jakichkolwiek innych ustaleń, poza wspomnianym stwierdzeniem nieuiszczenia grzywny w terminie. Stosowanie kary aresztu zastępczego nie wymagało zatem wszechstronnego zbadania okoliczności sprawy, w tym ustalenia faktycznej możliwości wywiązania się z obowiązku dostaw przez

${ }^{60}$ A. Gubiński, Ewolucja stosowanych przez kolegia środków..., s. 28.

${ }^{61}$ Ibidem, s. 28-29.

${ }^{62}$ R. Rajkowski, Prawo..., s. 81, przypis nr 6.

${ }^{63}$ Dekret z 4 marca 1953 r. o uzupełnieniu przepisów karnych w sprawach dostaw obowiązkowych (Dz. U. Nr 14, poz. 55).

${ }^{64}$ J. Chełmoński, J. Malinowski, Otrzymałem wezwanie do kolegium karno-administracyjnego, Warszawa 1957, s. 5.

${ }^{65}$ Dekrety z 4 marca 1953 r. : o wzmożeniu walki z produkcją złej jakości (Dz. U. Nr 16, poz. 63); o ochronie interesów nabywców w obrocie handlowym ( Dz. U. Nr 16, poz. 64); o wzmożeniu ochrony własności społecznej (Dz.U. Nr 17, poz. 68); o ochronie własności społecznej przed drobnymi kradzieżami (Dz. U. Nr 17, poz. 69).

${ }^{66}$ J. Szumski, Środki penalne w polskim prawie wykroczeń na tle doświadczeń praktyki, Lublin 1995, s 51 .

${ }^{67}$ R. Rajkowski, Prawo..., s. 94.

${ }^{68}$ B. Adamiak, Ewolucja systemu kar $w$ orzecznictwie $w$ sprawie wykroczeń $w$ PRL, „Acta Universitatis Wratislaviensis, Przegląd Prawa i Administracji”, Wrocław 1976, s. 107. 
obwinionego. Zmuszone przez ustawodawcę do mechanicznego orzekania kary grzywny z zamianą na areszt zastępczy kolegia nie mogły odstąpić od ustalenia w orzeczeniu tej ostatniej kary pod wpływem takich okoliczności, jak stopień zawinienia sprawcy, jego warunki społeczne, osobiste i materialne ${ }^{69}$.

Restrykcyjność wprowadzonych dekretem z 4 marca 1953 r. rozwiązań przejawiała się w ustanowieniu sześciomiesięcznego wymiaru zastępczej kary aresztu, podczas gdy obowiązujące przepisy materialnego prawa wykroczeń przewidywały karę aresztu do trzech miesięcy. Bardzo niekorzystnie z punktu widzenia ukaranych chłopów została ukształtowana relacja między kwotą niezapłaconej grzywny a wymiarem zastępczej kary aresztu, gdyż jeden dzień aresztu traktowano jako równoważnik $15 \mathrm{złotych}^{70}$. Wynika $\mathrm{z}$ tego, że miesiąc pobytu $\mathrm{w}$ areszcie stanowił konsekwencję niezapłacenia grzywny $\mathrm{w}$ wymiarze 450 złotych, podczas gdy grzywny wymierzane przez kolegia "bogatym chłopom” oscylowały wokół górnej granicy tej kary wynoszącej 3000 złotych. Łatwo w tym miejscu zauważyć, że rolnik względem którego zastosowano „surową represję karno-administracyjną" musiał liczyć się z sześciomiesięcznym pobytem w miejscu odosobnienia.

Innym wyrazem restrykcyjności dekretu z 4 marca 1953 r. był brak możliwości przedterminowego zwolnienia ukaranego $\mathrm{z}$ aresztu, gdyż dekret nie przewidywał stosunkowego zmniejszenia zastępczej kary aresztu w wyniku późniejszego częściowego zapłacenia grzywny ${ }^{71}$. Również wykonanie dostaw przez rodzinę osadzonego $\mathrm{w}$ areszcie chłopa nie stanowiło przesłanki do przedterminowego zwolnienia ukaranego. Możliwe było jedynie udzielenie przez prezydium rady narodowej odroczenia lub przerwy w wykonywaniu zastępczej kary aresztu, co wynikało z ogólnych rozwiązań dotyczących wykonywania orzeczeń i nakazów karnych wydanych przez kolegia ${ }^{72}$. Taka sytuacja była swego rodzaju kuriozum, gdyż obowiązujące przepisy przewidywały przedterminowe zwolnienie osób skazanych na karę pozbawienia wolności ${ }^{73}$, czyli sprawców czynów o dużo większym ciężarze gatunkowym niż niewykonanie dostaw obowiązkowych w terminie. Stosowanie instytucji warunkowego przedterminowego zwolnienia względem chłopów odbywających zastępczą karę aresztu przekreślał fakt, że decyzja w tej sprawie należała do kompetencji sądów, których jurysdykcja nie obejmowała spraw o wykroczenia ${ }^{74}$.

${ }^{69}$ M. Jaroszyński, M. Zimmermann, W. Brzeziński, Polskie prawo..., s. 422.

${ }^{70}$ J. Jakubowska-Hara, Grzywna..., s. 46.

${ }^{71}$ J. Szumski, Środki penalne..., s. 50.

${ }^{72}$ Kwestie te regulowało rozporządzenie Rady Ministrów z 15 grudnia 1951 r. w sprawie wykonywania orzeczeń i nakazów karnych wydanych przez kolegia przy prezydiach rad narodowych $(\mathrm{Dz}$. U. $\mathrm{Nr}$ 66, poz. 456).

${ }^{73}$ Ustawa z 31 października 1951 r. o warunkowym przedterminowym zwolnieniu osób odbywających karę pozbawienia wolności (Dz. U. Nr 58, poz. 399).

${ }^{74}$ I. Klajnerman, Niektóre zagadnienia $z$ dziedziny orzecznictwa karno-administracyjnego, „Nowe Prawo" 1955, nr 5, s. 101. 


\section{Praktyka stosowania zastępczej kary aresztu}

Wprowadzenie zastępczej kary aresztu znacznie wzmocniło skuteczność represji karno-administracyjnej w sprawach o dostawy obowiązkowe, do czego w największym stopniu przyczynił się rygorystyczny tryb stosowania tej kary. Stwierdzenie faktu nieuiszczenia grzywny przez ukaranego chłopa pociągało za sobą wysłanie przez referat społeczno-administracyjny prezydium gminnej rady narodowej stosownej informacji do powiatowej komendy Milicji Obywatelskiej, gdzie miały zgłaszać się osoby ukarane celem odbycia zastępczej kary aresztu. W całej tej procedurze nie występowały referaty finansowe prezydiów rad narodowych, których czynności w zakresie egzekucji orzeczonych kar grzywny nie miały bezpośredniego związku ze stosowaniem aresztu zastępczego. Można pokusić się zatem o stwierdzenie, że oprócz czynników ideowo-politycznych u podstaw wydania dekretu z 4 marca $1953 \mathrm{r}$. legły względy praktyczne związane $\mathrm{z}$ niskim poziomem pracy aparatu finansowego i egzekutorów. Pominięcie tych organów w procedurze stosowania zastępczej kary aresztu zdecydowanie wzmocniło pozycję kolegiów orzekających, na których barkach spoczywał teraz główny ciężar odpowiedzialności za planowe wykonywanie dostaw obowiązkowych.

Podsumowując pierwszy rok obowiązywania dekretu z 4 marca 1953 r., stwierdzono, że „wpływ orzecznictwa karno-administracyjnego na wykonanie obowiązkowych dostaw był widoczny"75, o czym świadczyć miało dostarczenie zaległych dostaw przez 44 procent ukaranych chłopów. Poprawa stanu wykonania dostaw była konsekwencją mechanicznego orzekania wysokich grzywien, których nieuiszczenie oznaczało perspektywę kilkumiesięcznego pobytu w areszcie. Rodziło to uzasadnione obawy ukaranych chłopów o dalsze losy pozostawionego bez należytej opieki gospodarstwa. Wzgląd na systematyczność prac rolnych i troska o rodzinę skutkowały podejmowaniem przez chłopów działań w kierunku wykonania dostaw i uniknięcia odpowiedzialności karno-administracyjnej. Z kolei chłopi już ukarani przez kolegia starali się w pierwszej kolejności zdobyć środki finansowe na opłacenie orzeczonej kary, gdyż tylko jej terminowe uiszczenie zwalniało od osadzenia w areszcie. W takiej sytuacji realizacja zaległych dostaw schodziła na dalszy plan, gdyż zgodnie z postanowieniami dekretu z 4 marca 1953 r. nie miało to żadnego wpływu na wykonanie zastępczej kary aresztu. Wybitnie represyjny charakter orzecznictwa karno-administracyjnego w sprawach o dostawy obowiązkowe prowadził do sytuacji, w których ukarani chłopi wyprzedawali inwentarz i wyposażenie gospodarstwa, byle tylko zapłacić wysokie grzywny. Ograniczało to możliwości produkcyjne gospodarstwa i stawiało pod znakiem zapytania dalsze wykonywanie przez właściciela

\footnotetext{
${ }^{75}$ Przed wyborami do kolegiów orzekających, „Rada Narodowa” 1954, nr 5, s. 30.
} 
obowiązków wobec państwa, w wyniku czego były kolejne wnioski o ukaranie za uchylanie się od obowiązku dostaw. Przykładem funkcjonowania spirali represji może być sprawa średniorolnego chłopa Gruszewskiego z powiatu Łapy, który „dwukrotnie karany za niewywiązywanie się z obowiązku dostaw, został ponownie ukarany grzywną z zamianą na areszt". Gruszewski zapłacił grzywnę, lecz żeby to uczynić musiał sprzedać konia, pozbawiając tym samym gospodarstwo siły pociągowej niezbędnej przy pracach polowych. Zdesperowany chłop udał się do prezydium powiatowej rady narodowej z prośbą o czasowe zwolnienie go z obowiązku dostaw. Dopiero po zbadaniu przez urzędników prezydium jego sprawy okazało się, że ukarany rolnik to „człowiek ciężko chory”, który „ma na utrzymaniu żonę i troje drobnych dzieci”, a jego gospodarstwo było tak zaniedbane, że dom groził zawaleniem ${ }^{76}$.

Przedstawiona sytuacja pokazuje mechanizm stosowania represji karno-administracyjnej przez kolegia, które pod wpływem presji władz zwierzchnich działały według zasady ,jak najszybciej karać" ${ }^{\prime \prime}$. Cechująca pracę aparatu skupu i prezydiów rad narodowych „zasada akcyjności” polegała na masowym sporząazaniu wniosków o ukaranie dopiero wtedy, gdy następowało załamanie planu dostaw na danym terenie. Celem ratowania zagrożonego planu dostaw prezydia powiatowych rad narodowych powoływały zwiększoną liczbę składów orzekających, aby szybko i sprawnie rozpatrzyć sporządzane naprędce wnioski o ukaranie. Pośpiech i presja w kierunku stosowania surowej represji karno-administracyjnej powodowały wydanie orzeczeń o ukaraniu grzywną na podstawie nieudokumentowanych i niestarannie przygotowanych wniosków. Mechaniczne orzekanie kar grzywny z zamianą na areszt, bez uprzedniego zbadania okoliczności sprawy i wysłuchania obwinionego, stanowiło praktyczny wyraz koncepcji kary administracyjnej jako instrumentu służącego planowemu wykonaniu dostaw obowiązkowych. Wychodząc z takiego założenia, członkowie niektórych kolegiów wymierzali surowe grzywny nawet wtedy, gdy z góry było wiadomo, że nie skłonią chłopa do wykonania zaległych dostaw, gdyż ten nie był w stanie sprostać swoim obowiązkom z przyczyn natury obiektywnej ${ }^{78}$.

Ponieważ wysokość orzeczonych grzywien często przekraczała możliwości finansowe ukaranych, następowała obligatoryjna zamiana nieuiszczonej grzywny na karę aresztu zastępczego. Osadzenie w areszcie ukaranego chłopa prowadziło $\mathrm{z}$ reguły do zaniedbania prac w gospodarstwie i sprzyjało powstaniu zaległości w wykonywaniu dostaw pozostałych płodów rolnych. Do aresztów trafiali chłopi zdolni do pracy, którzy odbywali karę w miejsce faktycznego właściciela gospo-

${ }^{76} \mathrm{~J}$. Bielecka, O skuteczności rozmów z obwinionymi o niewykonanie dostaw, „Poradnik dla Kolegiów Orzekających" 1956, nr 1, s. 11.

${ }_{77}$ Z. Orłowski, O pracy kolegiów orzekających w kampanii obowiązkowych dostaw, „Poradnik dla Kolegiów Orzekających" 1956, nr 1, s. 5-6.

${ }^{78}$ Ibidem, s. 5-6, 11. 
darstwa, jeżeli ten był osobą chorą, ułomną lub w podeszłym wieku. Ponieważ względem takich osób wykonanie kary aresztu zastępczego było utrudnione, to powszechnie stosowaną praktyką stało się poszukiwanie tzw. „użytkowników gospodarstwa”. Jako „użytkowników gospodarstwa” traktowano pozostałe osoby zamieszkałe we wspólnym gospodarstwie domowym z osobą ukaraną, czyli w praktyce synów prawowitego właściciela. W razie wydania kolejnych orzeczeń o ukaraniu, do aresztu trafiali po kolei wszyscy synowie właściciela gospodarstwa, który ze względu na stan zdrowia nie mógł odbywać zastępczej kary aresz$\mathrm{tu}^{79}$. Dochodziło więc do sytuacji, w której obowiązek prowadzenia gospodarstwa i realizacji kolejnych dostaw obowiązkowych spoczywał na niezdolnym do pracy na roli faktycznym właścicielu gospodarstwa.

Praktykę stosowania zastępczej kary aresztu i jej wpływ na realizację planu dostaw obowiązkowych zaprezentuję na podstawie danych statystycznych z pierwszych siedmiu miesięcy 1955 r. Dotyczą one orzeczeń kolegiów w sprawach o niewykonanie dostaw żywca i mleka. Wprawdzie statystyki te nie obejmują najważniejszych $\mathrm{z}$ punktu widzenia polityczno-gospodarczego dostaw zboża, lecz są w pełni miarodajne dla stworzenia obrazu skuteczności represji karno-administracyjnej. Według informacji sprawującego zwierzchni nadzór nad orzecznictwem karno-administracyjnym Ministerstwa Spraw Wewnętrznych $^{80}$ (MSW) w okresie od stycznia do końca lipca 1955 r. prezydia rad narodowych skierowały do organów MO 14540 wniosków o wykonanie zastępczej kary aresztu orzeczonej w sprawach o niewykonanie dostaw mleka i żywca. W tym czasie 70\% ukaranych przez kolegia chłopów zrealizowało dostawy, co należy rozumieć jako wyrównanie zaległości w dostawach przed stawieniem się ukaranego w komendzie MO w celu odbycia kary lub przez rodziny osadzonych w areszcie chłopów. Świadczy to o wykorzystywaniu zastępczej kary aresztu jako środka presji wywieranej na rodziny osadzonych, którym obiecywano uchylenie orzeczenia kolegium o ukaraniu grzywną w trybie nadzoru przez prezydium wojewódzkiej rady narodowej ${ }^{81}$, jeżeli tylko zostaną wyrównane zaległości w dostawach. Uchylenie orzeczenia w trybie nadzoru oznaczało wcześniejsze zwolnienie osadzonego chłopa $z$ aresztu, przez co faktyczna represyjność zastępczej kary aresztu była w pewnym stopniu łagodzona na etapie wykonywania kary. Tego

79 Opinia Zarządu Spraw Wewnętrznych Wojewódzkiej Rady Narodowej w Poznaniu z 13 czerwca 1957 r. odnośnie do projektu ustawy o uchyleniu dekretu z dnia 4 marca 1953 r., Instytut Pamięci Narodowej w Warszawie, Biuro Udostępniania i Archiwizacji Dokumentacji, zespół akt MSW II, sygn. teczki 6483, s. 99 (IPN BUiAD MSW II 4, s. 99).

${ }^{80}$ Przysługujący MSW od 1954 r. zwierzchni nadzór nad orzecznictwem kolegiów wykonywało Biuro Nadzoru nad Orzecznictwem Karno-Administracyjnym. W 1958 r. kompetencje w tym zakresie zostaną przekazane Departamentowi Społeczno-Administracyjnemu MSW.

${ }^{81}$ Zgodnie z postanowieniami art. 45 ust. 1. ustawy z 15 grudnia 1951 r. „prezydium wojewódzkiej rady narodowej może w trybie nadzoru uchylić prawomocne orzeczenie lub nakaz karny, pozbawione podstawy prawnej lub oczywiście niesłuszne". 
rodzaju praktyka była stosowana względem mało- i średniorolnych chłopów i opierała się na założeniu wychowawczego oddziaływania kary administracyjnej na ukaranego i jego środowisko. Rezygnacja z wykonania kary lub wcześniejsze zwolnienie $\mathrm{z}$ aresztu miały stanowić wyraz tego, że ukarany „zrozumiał swe obowiązki obywatelskie" i będzie zajmował odpowiednią postawę społeczną ${ }^{82}$.

\section{Wpływ „odwilży” na orzecznictwo kolegiów w dziedzinie dostaw obowiązkowych}

Represyjność zastępczej kary aresztu skutkowała coraz częstszym odchodzeniem przez prezydia rad narodowych od rygorystycznego stosowania przepisów dekretu z 4 marca 1953 r. w kierunku egzekwowania kary grzywny pomimo upływu terminu jej zapłacenia. Zapłacenie grzywny po terminie w połączeniu ze złożonym przez ukaranego zobowiązaniem uregulowania zaległości w dostawach skutkowało zaniechaniem wykonania zastępczej kary aresztu przez prezydia rad narodowych, chociaż formalnie nie były one uprawnione do podejmowania tego rodzaju działan ${ }^{83}$. Według danych statystycznych obejmujących pierwsze siedem miesięcy 1955 r. w areszcie osadzono jedynie 33\% ogółu ukaranych karą grzywny z zamianą na areszt zastępczy ${ }^{84}$, wskutek czego MSW stwierdziło, że „przy odpowiednim postępowaniu ilość osób osadzonych w areszcie może ulec wydatnemu zmniejszeniu"85.

Powyższe stwierdzenie obrazuje wpływ coraz bardziej widocznych oznak polityki „odwilży” na kierunek stosowania represji karno-administracyjnej w sprawach o dostawy obowiązkowe. Jeszcze w 1954 r. traktowano wymierzanie surowych kar w kategoriach wzmocnienia dyscypliny wykonania dostaw, ale w kolejnym roku zaczęto podkreślać znaczenie oddziaływania wychowawczego „jako podstawowej metody działania”. Wskazywano na potrzebę maksymalnego wykorzystania środków wychowawczych, a dopiero w dalszej kolejności zalecano sięganie do kary administracyjnej, która miała być „ostatnim w tym szeregu surowym środkiem wychowawczym" ${ }^{\text {". }}$. Według kształtującej się w okresie „odwilży” nowej koncepcji wykorzystania kolegiów w „kampanii dostaw obo-

${ }^{82}$ I. Klajnerman, Niektóre zagadnienia..., s. 101

${ }^{83}$ Ibidem.

${ }^{84}$ „Po otrzymaniu wezwania M.O. do odbycia kary $12 \%$ ukaranych uiściło grzywnę, 31 \% wykonało dostawy przed umieszczeniem w areszcie, co skutkowało odstąpieniem od wykonania kary aresztu względem tych osób. Wobec 14 \% ukaranych zrezygnowano z wykonania zastępczej kary aresztu powołując się na takie powody jak wiek, czy warunki rodzinne". Notatka MSW z 17 sierpnia 1955 r. w sprawie trybu wykonania zastępczej kary aresztu, IPN BUiAD MSW II 6438, s. 46.

${ }^{85}$ Notatka MSW z dnia 17 sierpnia 1955 r. w sprawie trybu wykonania zastępczej kary aresztu, IPN BUiAD MSW II 6438, s. 46.

${ }^{86}$ Z. Orłowski, O pracy kolegiów orzekających..., s. 4-5. 
wiązkowych", ich głównym zadaniem była pomoc w terminowej realizacji dostaw przez umiejętne stosowanie represji karno-administracyjnej. Od członków składów orzekających zaczęto wymagać „pogłębienia pracy organizacyjno-wychowawczej, stosowania sankcji karno-administracyjnej jedynie w wypadkach niezbędnych, a więc gdy inne środki zawiodą, zwiększenia trafności i skuteczności orzekanych kar" ${ }^{\prime 7}$. Nowym wymogom towarzyszyła ostrożna jeszcze krytyka „akcyjności” działania kolegiów w poprzednich latach, gdyż jak stwierdzono „Zamiast pracować systematycznie, kolegia dały się niekiedy ponieść akcyjności i poddawały się atmosferze nerwowości"88. Skutkiem tego miały być nieprawidłowości w stosowaniu przepisów prawnych, zwłaszcza dekretu z 4 marca 1953 r. Skalę tych nieprawidłowości oddaje przeprowadzona w 1955 r. przez prokuraturę ogólnokrajowa kontrola orzeczeń kolegiów w sprawach o niewykonanie dostaw obowiązkowych. Prokuratorzy zakwestionowali legalność 34,4\% zapadłych orzeczeń jako niesłusznie wydanych, stwierdzając, że w znacznej części spraw w ogóle nie powinny zapaść orzeczenia skazujące. W wyniku podjętych przez prokuraturę działań w kierunku uchylenia niesłusznie zapadłych orzeczeń zarządzono przerwę w odbywaniu zastępczej kary aresztu względnie definitywnie zwolniono z zakładów penitencjarnych ponad 5 tysięcy osadzonych tam chłopów ${ }^{89}$.

Kwestionując na fali polityki „odwilży” nadmierną represyjność orzecznictwa karno-administracyjnego, MSW nakazało kolegiom umiejętne stosowanie środków karnych w myśl zasady, że „zmniejszenie karania bynajmniej nie oznacza osłabienia pracy kolegiów"90. Umiejętne stosowanie represji karno-administracyjnej nie oznaczało jeszcze całkowitego pominięcia klasowych aspektów polityki karnej, gdyż wobec „opornych, kułaków i spekulantów” zalecano wymierzanie surowych kar „Z całą ostrością". Te grupy ludności wiejskiej miały być karane w ten sposób za złośliwe niewykonywanie obowiązków wobec państwa i negatywne oddziaływanie swoim przykładem na pozostałych chłopów zalegających $\mathrm{z}$ dostawami. Natomiast $\mathrm{w}$ stosunku do przeciwstawianych kułakom

${ }^{87}$ Ibidem.

${ }^{88}$ Ibidem.

${ }^{89}$ „W okresie od 1 stycznia do 20 listopada 1955 r. organa prokuratury przeanalizowały 37079 spraw, w których zapadły orzeczenia skazujące za niewykonywanie dostaw obowiązkowych. W wyniku tej analizy organa prokuratury zakwestionowały 12609 spraw, tj. 34,4\%, jako zawierające niesłuszne orzeczenia. W tej liczbie mieściło się 5077 spraw, w których nie powinny zapaść orzeczenia skazujące. W związku z tym prokuratorzy wystąpili o uchylenie 5425 orzeczeń oraz spowodowali przerwę w odbywaniu zastępczej kary aresztu, względnie spowodowały zwolnienie z zakładów penitencjarnych 5064 osób, odbywających zastępczą karę aresztu". Sprawozdanie z działalności Departamentu Nadzoru Ogólnego i podległych mu pionów terenowych w 1955 r., Archiwum Akt Nowych, zespół akt Prokuratura Generalna, sygn. teczki 14, s. 129.

${ }^{90}$ J. Kucharski, W przededniu kampanii skupu zboża, „Poradnik dla Kolegiów Orzekających” 1956, nr 4, s. 3. 
tzw. „chłopów pracujących” miały być stosowane „w pierwszym rzędzie metody wyjaśniania, przekonywania, oddziaływania wychowawczego"91.

Złagodzenie represyjności orzecznictwa karno-administracyjnego pociągnęło za sobą powolne kształtowanie się nowego stylu pracy kolegiów, których wyznacznikiem była skuteczność oddziaływania wychowawczego w kierunku dobrowolnego wyrównania przez chłopów zaległości w dostawach. Zalecając jako reakcję na problemy $\mathrm{z}$ wykonaniem planu dostaw zboża w 1955 r. wzmożenie aktywności kolegiów, MSW wyraźnie podkreślało, że nie należy tego utożsamiać ze zwiększeniem liczby kar, lecz z położeniem szczególnego nacisku na rozmowy z obwinionymi chłopami. Najważniejszym punktem rozmów z obwinionymi było uprzedzanie zalegających z dostawami „opornych” chłopów o konsekwencjach, jakie będą musieli ponieść $\mathrm{w}$ razie niewykonania w terminie swoich obowiązków. Użycie przymiotnika „oporny” wskazuje na próbę ograniczenia zakresu represji karno-administracyjnej do grupy chłopów posiadających faktyczne możliwości wykonania dostaw. Widać w tym próbę realizacji postulatu stosowania sankcji „ze szczególną wnikliwością i rozwagą” tak, „aby nie dopuścić do wydawania orzeczeń nietrafnych"92. Podkreślono przy tym odpowiedzialność ciążącą na członkach składów orzekających kolegiów, którzy mieli dopilnować, żeby „nie przeszedł żaden nietrafny lub krzywdzący wniosek” ${ }^{\text {. }}$.

Zdaniem MSW, rozmowy $\mathrm{z}$ chłopami przynosiły oczekiwane rezultaty w postaci dobrowolnego wyrównania zaległości w dostawach przez większość obwinionych. Przytaczano przykład województwa poznańskiego, gdzie po otrzymaniu 600 wniosków o ukaranie członkowie kolegiów powiatowych zamiast masowo karać, udali się do poszczególnych gromad celem przeprowadzenia rozmów z obwinionymi chłopami. Skutkiem tych rozmów było wykonanie dostaw przez 500 chłopów, bez potrzeby uciekania się do stosowania represji karno-administracyjnej ${ }^{94}$.

Rozprawy pokazowe „organizowane w gromadach i wsiach w obecności obwinionych i miejscowej ludności" stanowiły kolejną z metod oddziaływania wobec zalegających z dostawami chłopów. Stosowanie tej metody spotkało się w 1955 r. z aprobatą MSW. Zmianie uległ charakter tych rozpraw, gdyż służyły one nie tyle stosowaniu środków represji względem „opornych” chłopów, co pu-

${ }^{91}$ Z. Orłowski, O pracy kolegiów orzekających..., s. 3-4.

${ }^{92}$ J. Kucharski, W przededniu kampanii..., s. 3.

${ }_{93}$ Z. Orłowski, O pracy kolegiów orzekających..., s. 8.

${ }^{94}$ Inny przykład to gromada Bartochów w powiecie sieradzkim, gdzie członkowie kolegium gromadzkiego przeprowadzali z własnej inicjatywy rozmowy z chłopami, wyjaśniając zalegającym w dostawach konieczność uregulowania zaległości jako warunku uniknięcia odpowiedzialności przed kolegium powiatowym. Skuteczność rozmów z chłopami miała wyrażać się w sporadycznych karach grzywny za niewykonywanie dostaw obowiązkowych, które zostały wymierzone przez kolegium powiatowe podczas rozprawy pokazowej w gromadzie. B. Wrzesińska, Nasze doświadczenia (na przykładzie gromadzkiego kolegium orzekającego w Bartochowie), „Poradnik dla Kolegiów Orzekających” 1956, nr 1, s. 30. 
blicznemu zobowiązaniu ich do szybkiego wyrównania zaległości w dostawach w zamian za odroczenie wykonania kary. Przykładowo we wspomnianym wcześniej województwie poznańskim spośród 100 chłopów wezwanych na rozprawy pokazowe ukarano tylko 40, gdyż „pozostali wykonali swe obowiązki przed lub po rozprawie, na którą zostali zaproszeni" ${ }^{\prime 5}$. Coraz częstsze przypadki rezygnacji z wykonywania orzeczonych kar w zamian za uregulowanie przez obwinionego zaległości $\mathrm{w}$ dostawach świadczą o postępującym procesie odchodzenia od represyjnego modelu polityki karno-administracyjnej. W 1955 r. znacząco zmniejszyła się liczba kar orzeczonych przez kolegia, do czego - zdaniem MSW - przyczyniły się „bardziej wnikliwa analiza wniosków, częstsze stosowanie postępowania wyjaśniającego, rozmowy prowadzone przed ukaraniem z zalegającymi w obowiązkowych dostawach"96.

Począwszy od 1955 r., w sposób elastyczny zaczęto traktować zastępczą karę aresztu, upatrując $w$ niej nie tyle instrumentu represji, co środka perswazji wobec zalegających $\mathrm{z}$ dostawami chłopów. Tytułem próby wprowadzono w poszczególnych powiatach nowy tryb stosowania kary. Według niego osadzenie ukaranego $\mathrm{w}$ areszcie nie następowało automatycznie, lecz było uzależnione od jego postawy po zapadnięciu orzeczenia kolegium. Wzywani do komend MO chłopi celem odbycia kary byli zwalniani, jeśli przedstawili kwity świadczące o pełnym wykonaniu zaległych dostaw, a prezydia powiatowych rad narodowych wycofywały wnioski o zastosowanie względem tych osób aresztu zastępczego. Chłopom wyrażającym chęć szybkiego uregulowania zaległości odraczano wykonanie kary aresztu zastępczego, z reguły do czasu zakończenia prac polowych związanych ze żniwami. W areszcie osadzano znikomą część wezwanych, z reguły byli to „oporni” chłopi, posiadający możliwości wykonania dostaw, lecz "złośliwie" uchylający się od tego obowiązku. Praktyczną stronę nowego trybu wykonywania zastępczej kary aresztu pokazują dane z pięciu powiatów województwa białostockiego, gdzie na 121 wezwanych celem odbycia kary chłopów jedynie 35 umieszczono $\mathrm{w}$ areszcie ${ }^{97}$.

Praktyka łagodzenia nadmiernej represyjności dekretu z 4 marca 1953 r. w drodze elastycznego stosowania zastępczej kary aresztu spotkała się z uznaniem zarówno członków składów orzekających kolegiów jak też pracowników referatów karno-administracyjnych. Również tzw. „aktyw terenowy” opowiadał się za wprowadzeniem nowego trybu wykonywania zastępczej kary aresz-

${ }^{95}$ Z. Orłowski, O pracy kolegiów orzekających..., s. 6.

${ }^{96} \mathrm{H}$. Chmielewski, O realizację orzeczeń kolegiów karno-administracyjnych, „Poradnik dla Kolegiów Orzekających" 1956, nr 2-3, s. 6.

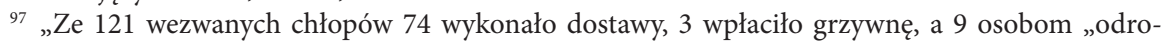
czono wykonanie kary w związku ze żniwami i przyrzeczeniem wykonania zaległości”. Z pozostałych 35 wezwanych 17 chłopów stawiło się dobrowolnie wyrażając wolę odbycia kary aresztu, natomiast 18 osób zostało przez M.O. przymusowo doprowadzonych do miejsca wykonania kary". Notatka MSW z 17 sierpnia 1955 r. w sprawie trybu wykonania..., s. 46-47. 
tu „jako bardziej skutecznej i wychowawczej"98. Postulaty te były połączone z coraz głośniejszą krytyką dekretu z 4 marca 1953 r., przy stosowaniu którego „popełniono wiele błędów, naruszając nawet niekiedy praworządność ludową". Podczas dwuletniego okresu obowiązywania dekretu dopuszczano się wypaczeń zwłaszcza wobec „starców, kalek, jedynych żywicieli rodzin i innych osób, w stosunku do których nie było faktycznej możliwości wykonania zastępczej kary aresztu"99.

\section{Nowelizacja dekretu z 4 marca 1953 r.}

Sprawujące zwierzchni nadzór nad orzecznictwem karno-administracyjnym MSW na fali polityki „odwilży” przyłączyło się do krytyki dotychczasowych rozwiązań, stwierdzając, „że orzekanie zastępczej kary aresztu w każdym przypadku karania za niewykonanie dostaw obowiązkowych jest niesłuszne i niecelowe"100. Uwaga ta dotyczyła przypadków, w których obligatoryjne wykonanie tej kary pozbawiało gospodarstwo jedynego zdolnego do pracy użytkownika. Chodziło również o sytuacje, w których ukaraniu podlegali chłopi niezdolni do pobytu $\mathrm{w}$ areszcie wskutek podeszłego wieku, kalectwa, inwalidztwa lub przewlekłej choroby. Reakcją na częste występowanie tego rodzaju wypaczeń było wydanie 27 września 1955 r. dekretu nowelizującego ${ }^{101}$, który przyznawał kolegiom powiatowym uprawnienia do zaniechania ustalania zastępczej kary aresztu oraz zaniechania wykonania tej kary ustalonej w orzeczeniu o ukaraniu. Kolegium mogło zaniechać ustalenia zastępczej kary aresztu jedynie w ściśle określonych przypadkach, uzasadnionych całokształtem okoliczności sprawy. W razie skorzystania przez kolegium z tego uprawnienia, orzeczona kara grzywny podlegała wykonaniu w trybie egzekucji administracyjnej świadczeń pieniężnych. Przesłanki leżące u podstaw przyznania kolegiom nowej kompetencji były podyktowane względami natury humanitarnej oraz koniecznością utrzymania zdolności produkcyjnej gospodarstwa. Miały one zastosowanie w sytuacji, gdy:

- w gospodarstwie nie było poza obwinionym zdolnego do pracy członka rodziny,

- obwiniony miał powyżej 65 lat, był kaleką, inwalidą lub człowiekiem przewlekle chorym,

98 Ibidem, s. 47-48.

99 Kiedy kolegium powiatowe może nie ustalić w orzeczeniu zastępczej kary aresztu?, „Poradnik dla Kolegiów Orzekających" 1956, nr 2-3, s. 48.

100 Uzasadnienie projektu dekretu nowelizującego dekret z 4 marca 1953 r. (12 marca 1955), IPN 6438 BUiAD MSW II 6438, s. 84.

101 Dekret z 27 września 1955 r. o zmianie dekretu z dnia 4 marca 1953 r. o uzupełnieniu przepisów karnych w sprawach o niewykonanie dostaw obowiązkowych (Dz. U. Nr 39, poz. 241). 
- obwiniona była wdową obarczoną dziećmi w wieku poniżej 14 lat, które wymagały stałej opieki matki.

Pod koniec grudnia 1955 r. w drodze wydania kolejnego dekretu ${ }^{102}$ katalog przesłanek zezwalających kolegium na zaniechanie ustalania zastępczej kary aresztu rozszerzono na sytuację, w której użytkownik gospodarstwa rolnego był zatrudniony w państwowym lub spółdzielczym zakładzie pracy. Rozwiązanie to wprowadzono celem zapewnienia normalnego funkcjonowania sektora przedsiębiorstw uspołecznionych, gdyż osadzanie $\mathrm{w}$ aresztach pracowników tych przedsiębiorstw „połączone było z odrywaniem tych osób od zajęć zawodowych, powodując zakłócenia w zakładach pracy"103. Powyższe wyliczenie okoliczności uzasadniających zaniechanie ustalania zastępczej kary miało charakter wyczerpujący, wobec czego kolegium nie mogło w drodze wykładni rozszerzającej skorzystać z przyznanej mu kompetencji w innych przypadkach ${ }^{104}$.

Drugą z przyznanych kolegiom w ramach nowelizacji dekretu 4 marca $1953 \mathrm{r}$. kompetencji - zaniechanie wykonania ustalonej w orzeczeniu o ukaraniu zastępczej kary aresztu - należy ocenić jako wyjście naprzeciw potrzebom dotychczasowej praktyki. Oficjalnie powoływano się na lansowany w okresie „odwilży” argument o wychowawczym charakterze represji karno-administracyjnej. Pod jego wpływem ustawodawca uznał, że „fakt wykonania obowiązku dostawy nawet po wydaniu orzeczenia o ukaraniu - powinien łagodzić sytuację ukaranego" ${ }^{105}$. Warunkiem umożliwiającym zastosowanie względem ukaranego chłopa tego rozwiązania było wykonanie w całości obowiązku dostawy, zarówno przed rozpoczęciem wykonywania, jak i w trakcie odbywania zastępczej kary aresztu. Zarządzenie przez kolegium niewykonania kary aresztu zastępczego oznaczało egzekucję orzeczonej grzywny w całości lub w części odpowiednio zmniejszonej $\mathrm{w}$ zależności od czasu pobytu ukaranego $\mathrm{w}$ areszcie ${ }^{106}$.

Praktyka stosowania znowelizowanych przepisów dekretu z 4 marca $1953 \mathrm{r}$. potwierdziła słuszność wprowadzonych rozwiązań, gdyż wyraźnie zmniejszyła się liczba osób, które w pełnym wymiarze odbyły zastępczą karę aresztu. Wskazują na to chociażby dane z terenu województwa lubelskiego, gdzie „w $1956 \mathrm{r}$. kolegia k.a. ukarały 2735 osób, z tego tylko 5 ukaranych wykonało karę aresztu $\mathrm{w}$ całości” ${ }^{107}$. Samo wezwanie do stawienia się w areszcie okazywało się z reguły

102 Dekret z 21 grudnia 1955 r. o zmianie dekretu z 4 marca 1953 r. o uzupełnieniu przepisów karnych w sprawach o niewykonanie dostaw obowiązkowych (Dz. U. Nr 46, poz. 312).

103 Uzasadnienie projektu dekretu z 21 grudnia 1956 r. o zmianie dekretu z 4 marca 1953 r., IPN BUiAD MSW II 6438, s. 52.

104 Uzasadnienie projektu dekretu nowelizującego..., s. 84.

105 I. Klajnerman, Z zagadnień orzecznictwa karno-administracyjnego, „Nowe Prawo” 1956, nr 9, s. 37.

106 Ibidem, s. 36-37.

107 Opinia Prezydium Wojewódzkiej Rady Narodowej w Lublinie z 31 maja 1957 r. o projekcie ustawy uchylającej dekret z 4 marca 1953 r., IPN BUiAD MSW II 6438, s. 107. 
skutecznym środkiem oddziaływania na ukaranych chłopów w kierunku szybkiego wyrównania zaległości $\mathrm{w}$ dostawach. Podkreślając walory profilaktyczno-wychowawcze nowego trybu stosowania zastępczej kary aresztu, Prezydium Wojewódzkiej Rady Narodowej w Lublinie wyraziło opinię, że „słusznie wymierzona kara prowadzi w zasadzie do wykonania dostaw, a tylko znikoma ilość ukaranych wykonuje w całości karę aresztu”108.

\section{Orzecznictwo karno-administracyjne w sprawach dostaw obowiązkowych w 1956 r.}

Liberalizacja represyjnych rozwiązań dekretu z 4 marca 1953 r. stanowiła oficjalne potwierdzenie zmiany polityki władz w zakresie dostaw obowiązkowych, która na fali wydarzeń przełomowego 1956 r. została definitywnie pozbawiona otoczki polityczno-ideologicznej. Nawiązując do nowego stylu pojmowania praworządności ludowej, w którego ramach eksponowano wymóg legalności działania aparatu państwowego, zaczęto zwracać większą uwagę na prawidłowe ustalanie wymiaru dostaw obowiązkowych przez terenowych pełnomocników Ministerstwa Skupu. Na mocy uchwały Prezydium Rządu o skupie zbóż ze zbiorów 1956 r. wprowadzono zmiany służące lepszemu dostosowaniu obciążeń nakładanych na poszczególnych chłopów do realnych możliwości ich gospodarstw. Wspomniana uchwała Prezydium Rządu zalecała zwrócenie wyjątkowej uwagi na właściwe ustalanie terminów dostaw zbóż, gdyż w tym zakresie „w latach ubiegłych popełniono wiele błędów”. Na fali rozliczeń z przeszłością okresu stalinowskiego oficjalnie przyznano, że „wadliwie ustalone terminy obowiązkowych dostaw zbóż, nie powiązane z możliwościami omłotów i przebiegiem innych prac rolnych przypadających $\mathrm{w}$ miesiącach sierpniu i wrześniu, utrudniały niektórym gospodarstwom terminowe wywiązanie się z obowiązków wobec państwa. Terminy te były ponadto często przyczyną zahamowań w przeprowadzaniu we właściwym czasie pilnych prac polowych"109. Celem zapobieżenia tego rodzaju wypaczeniom uchwała Prezydium Rządu ustalała pierwsze terminy dostaw zbóż w zależności od okresu dojrzewania zboża w poszczególnych rejonach kraju. Wprowadzono nowy sposób ustalania terminów dostaw na specjalnie $\mathrm{w}$ tym celu zorganizowanych zebraniach gromadzkich. Uzgadnianie z rolnikami terminów dostaw zboża stanowiło przejaw traktowania przez władze dostaw obowiązkowych w kontekście ekonomicznym, w myśl zasady, że „Państwo ma

108 Ibidem.

109 J. Kucharski, W przededniu kampanii..., s. 1. 
na celu przede wszystkim zwiększenie zainteresowania produkcją rolną i uniknięcie niepotrzebnych strat" ${ }^{\prime 10}$.

Zmianie sposobu działania aparatu skupu towarzyszyło wyznaczenie nowych priorytetów polityki karno-administracyjnej, która „słusznie” stosowana miała przyczynić się do całkowitego wykonania planu dostaw obowiązkowych. $\mathrm{W}$ porównaniu z okresem stalinowskim „słuszność” stosowania sankcji karno-administracyjnych nabrała nowego znaczenia. W 1956 r. miała przejawiać się $\mathrm{w}$ wychowawczej roli orzecznictwa kolegiów i „powiązaniu go z pracą polityczno-uświadamiającą". Konsekwencją zmian kierunku polityki represyjnej było przejście kolegiów „na metody pracy szeroko uwzględniające elementy profilaktyczne i wychowawcze"111. Znacznie zmniejszył się udział spraw o niewykonanie dostaw obowiązkowych w ogólnej strukturze wykroczeń rozpatrywanych przez kolegia, co stwierdziło MSW, dokonując przeglądowej analizy orzecznictwa karno-administracyjnego w $1956 \mathrm{r}$. na tle lat poprzednich ${ }^{112}$. W porównaniu z $1955 \mathrm{r}$. zanotowano drastyczny wręcz spadek liczby ukaranych chłopów, gdyż od początku roku do 15 września 1956 r. ukarano zaledwie 435 osób zalegających z dostawami zboża, „podczas gdy do 15 września 1955 r. kolegia ukarały 9520 osób”. Zdaniem MSW, przyczyny takiego stanu tkwiły nie tylko w zmianie stylu pracy kolegiów, lecz także w czynnikach związanych z klimatem społeczno-politycznym przełomowego dla powojennych dziejów Polski roku 1956. Prezydia rad narodowych znajdowały się wówczas pod presją ludności wiejskiej, która wykorzystując kryzys systemu stalinowskiego, żądała zmiany sposobu prowadzenia polityki państwa wobec rolników indywidualnych, w tym zniesienia dostaw obowiązkowych. Oznaki tzw. „rozprężenia” dotknęły także aparat Ministerstwa Skupu, który był niepewny swej przyszłości wobec „uporczywie krążących pogłosek o zamiarze Rządu całkowitego zniesienia dostaw obowiązkowych”. Skutkiem tego były częste przypadki uchylania się od sporządzania wniosków o ukaranie, przez co otrzymujące małe ilości wniosków kolegia „w zasadzie nie prowadziły szerszej działalności”. Wśród członków składów orzekających kolegiów miało występować „niezdecydowanie oraz przekonanie, że dostawy obowiązkowe, szczególnie zboża, wykonane zostaną samorzutnie"113.

Ogólne rozprężenie widoczne w pracy aparatu skupu i prezydiów rad narodowych oraz przekonanie ludności wiejskiej, że zniesienie dostaw obowiązkowych to tylko kwestia czasu, skutkowały bardzo słabą realizacją planu dostaw

110 Ibidem, s. 2.

111 Ibidem, s. 3-4.

112 Podsumowując działalność orzecznictwa karno-administracyjnego w 1956 r., stwierdzono, że „poważnie zmniejszyła się (więcej niż 50\%) ilość kar wymierzanych za niewywiązywanie się z obowiązkowych dostaw”. H. Chmielewski, Orzecznictwo karno-administracyjne w 1956 r., „Poradnik dla Kolegiów Orzekających" 1957, nr 1-2, s. 4.

113 Notatka informacyjna dla Kolegium Ministerstwa Spraw Wewnętrznych o przebiegu orzecznictwa karno-administracyjnego w roku 1956, IPN BUiAD MSW II 4, s. 283-284. 
zboża. Realne zagrożenie wykonania planu dostaw podziałało w sposób mobilizujący na aparat skupu, który zaczął w szerszym zakresie sporządzać wnioski o ukaranie, „toteż w ciągu 6 tygodni od 15 września do 31 października kolegia ukarały 7004 osoby". Zwiększenie aktywności kolegiów nie szło jednak w parze ze skuteczną egzekucją orzeczonych kar, gdyż w „prezydiach rad narodowych powstały wątpliwości co do potrzeby wykonania orzeczonych kar”. Taka postawa prezydiów prowadziła do powstania poważnych zaległości w sferze wykonawstwa kar, gdyż „na dzień 31 grudnia było niewykonanych około 3000 kar orzeczonych przez kolegia, chociaż ukarani dostaw nie wykonali"114.

Wraz z przejęciem steru rządów przez ekipę Gomułki system komunistyczny szybko odzyskał pewność siebie, zdecydowanie tłumiąc wszelkie przejawy „rozprężenia", jakiemu w okresie wydarzeń 1956 r. uległ aparat państwowy. Również kolegia karno-administracyjne szybko w zasadzie otrząsnęly się z "marazmu” i po wyborach członków składów orzekających 20 stycznia 1957 r. „przystąpiły energiczniej do pracy"115. Nie oznaczało to jednak istotnych zmian w sposobie stosowania represji karno-administracyjnej w sprawach o dostawy obowiązkowe. W tej dziedzinie zdobycze Października okazały się na tyle trwałe, że w pierwszej połowie 1957 r. poważnie rozważano całkowite zniesienie zastępczej kary aresztu w drodze uchylenia dekretu z 4 marca 1953 r.

\section{Próby uchylenia dekretu z 4 marca 1953 r.}

Dyskusja wokół celowości dalszego obowiązywania tego dekretu stanowiła pokłosie prowadzonych od lipca 1955 r. prac nad uporządkowaniem przepisów w dziedzinie orzecznictwa karno-administracyjnego. Efektem tych prac było opracowanie pod koniec 1956 r. przez MSW projektu Prawa Karno-Administracyjnego ${ }^{116}$. Twórcy projektu stali na stanowisku potrzeby złagodzenia represji karno-administracyjnej, wobec czego wśród kar przewidzianych w projekcie nie znalazła się zastępcza kara aresztu. Dotychczasowe stosowanie tej kary oceniono bardzo krytycznie, stwierdzając, że „pochopne, a wielokroć wręcz niesprawiedliwe orzeczenia $\mathrm{w}$ tych sprawach [o niewykonanie dostaw obowiązkowych przyp. M.Ł.], kończące się często pozbawieniem ukaranego wolności na okres do 6 miesięcy, były źródłem nieraz ciężkich krzywd moralnych i materialnych”. Trudno nie zgodzić się z tą oceną, toteż za w pełni wystarczające uznano orzekanie w sprawach o niewykonanie dostaw obowiązkowych kary grzywny bez

114 Ibidem, s. 283.

115 Ibidem, s 284.

116 Roboczy projekt Prawa Karno-Administracyjnego został opracowany przez Biuro Nadzoru nad Orzecznictwem Karno-Administracyjnym Ministerstwa Spraw Wewnętrznych, IPN BUiAD MSW II 4, s. 261. 
możliwości jej zamiany na areszt zastępczy. Wyrażano przy tym uzasadnione sytuacją w kraju na przełomie lat 1956/1957 przekonanie, że „nowa polityka gospodarcza wobec wsi łącznie z perspektywą ograniczenia obowiązku dostaw zmniejszy zapewne w dużej mierze potrzebę uciekania się do ostrej represji”117.

Nawiązując do założeń projektu Prawa Karno-Administracyjnego, MSW wyszło z propozycją całkowitego uchylenia dekretu z 4 marca $1953 \mathrm{r}$. W tym celu przygotowało w maju 1957 r. stosowny projekt ustawy. Uzasadniając potrzebę wyeliminowania zastępczej kary aresztu, powoływano się na wyjątkowość tego środka represyjnego, stojącą w sprzeczności z podstawowymi założeniami socjalistycznego modelu orzecznictwa karno-administracyjnego. Świadczyć miał o tym fakt, że ustawa z 15 grudnia $1951 \mathrm{r}$. „wprowadziła zamiast kary aresztu karę pracy poprawczej i nie uznaje również zastępczej kary aresztu"118. Wprowadzenie do orzecznictwa karno-administracyjnego na zasadzie wyjątku zastępczej kary aresztu wywołało zamęt w polityce karnej kolegiów, gdyż kara ta nie mogła być stosowana $\mathrm{w}$ sprawach o znacznie bardziej społecznie niebezpieczne wykroczenia chuligańskie. Przewidziana dekretem z 4 marca 1953 r. odmienna procedura wykonywania orzeczeń o ukaraniu w sprawach o dostawy obowiązkowe sprzyjała powstaniu różnorodnych wypaczeń wynikających z nadużywania przez kolegia przysługującego im szczególnego uprawnienia ${ }^{119}$. MSW wyrażało w związku z tym przekonanie, że tak dotkliwa kara jak pozbawienie wolności powinna być orzekana wyłącznie w postępowaniu karno-sądowym. Praktyka rozpatrywania przez kolegia spraw o wykroczenia w ramach procedury zawartej w ustawie z 15 grudnia $1951 \mathrm{r}$. nie dawała takich możliwości ścisłego ustalenia prawdy materialnej i rozważenia wszystkich okoliczności sprawy, jaką posiadały w trybie postępowania karnego sądy. Stąd postulat pozostawienia w wyłącznej gestii sądownictwa uprawnień do wymierzania kar pozbawienia wolności i aresztu za złośliwe, czyli wielokrotne uchylanie się od wykonania obowiązku dostaw. Kolegia natomiast miały orzekać kary grzywny względem sprawców wykroczeń polegających na jednorazowym zaleganiu $z$ dostawami. Orzeczone przez kolegia grzywny podlegałyby w razie nieuiszczenia egzekucji w trybie administracyjnego postępowania przymusowego. Zdaniem MSW, sankcje karno-sądowe w połączeniu z postępowaniem przymusowym „stwarzają dostateczny zespół środków represyjnych zapewniających prawidłową realizację obowiązkowych dostaw"120.

Projekt ustawy uchylającej dekret z 4 marca 1953 r. został rozesłany przez MSW wybranym ministerstwom, prokuratorowi generalnemu oraz kierownikom wojewódzkich zarządów spraw wewnętrznych celem zasięgnięcia opinii.

117 Uzasadnienie projektu Prawa Karno-Administracyjnego, IPN MSW II 4, s. 230, 232.

118 Uzasadnienie projektu ustawy uchylającej dekret z 4 marca 1953 r. (maj 1957 r.), IPN BUiAD MSW II 6438, s. 114 .

119 W. F. Dąbrowski, Zagadnienia ogólne..., s. 111.

120 Uzasadnienie projektu ustawy uchylającej dekret z 4 marca 1953 r. ..., s. 114-115. 
Z wyjątkiem kierownika zarządu w Lublinie, pozostałe instytucje wypowiedziały się za projektem, uznając go „za celowy i pożyteczny”. Niektóre zarządy spraw wewnętrznych posunęły się jeszcze dalej, proponując całkowite zniesienie karania w trybie karno-administracyjnym za niewykonanie dostaw obowiązkowych i ograniczenie się do stosowania środków przewidzianych w administracyjnym postępowaniu przymusowym. Przeciwny uchyleniu dekretu z 4 marca 1953 r. kierownik Zarządu Spraw Wewnętrznych w Lublinie stał na stanowisku, że "utrzymanie zastępczej kary aresztu w sprawach o dostawy obowiązkowe jest konieczne dla prawidłowej realizacji dostaw". To właśnie orzeczenia o zastępczej karze aresztu miały być czynnikiem skłaniającym rolników do wykonania dostaw, „poza tym Lublin obawiał się długiego trybu przeprowadzania egzekucji kar pieniężnych"121.

Argumenty przemawiające za utrzymaniem znowelizowanego dekretu z 4 marca 1953 r. nieoczekiwanie zyskały uznanie w oczach kierownictwa MSW, które pod wpływem nacisków ze strony władz partyjno-państwowych zaczęło w sposób bardziej represyjny kształtować politykę karno-administracyjną. Po szybkim zdobyciu pełni władzy w kraju, ekipa Gomułki rozpoczęła wyraźny odwrót od liberalnych metod sprawowania rządów, wygaszając rozbudzone wydarzeniami października 1956 r. nadzieje społeczne na demokratyzację systemu komunistycznego w Polsce. Traktując przejawy liberalizmu działania aparatu państwowego jako oznaki słabości władzy, Gomułka przyjął zdecydowaną postawę wobec wszelkich przypadków „łamania przez obywateli praworządności ludowej”. Pod wpływem doraźnych potrzeb politycznych istotę tej praworządności zaczęto upatrywać nie tyko w respektowaniu praw obywateli, lecz także w egzekwowaniu wykonywania przez nich obowiązków na rzecz państwa ${ }^{122}$. Ważną rolę w procesie "przywracania poszanowania obowiązującego prawa” miały spełniać kolegia karno-administracyjne, stąd też kierowane do nich od połowy 1957 r. przez MSW dyrektywy podkreślały potrzebę zaostrzenia represji oraz przestrzegały przed „błędnym” poglądem, iż „praworządność to łagodność" ${ }^{23}$. Dyrektywy wyraźnie podkreślały, że „ze zjawiskiem niczym nieuzasadnionej łagodności trzeba zdecydowanie skończyć”, gdyż „łagodne kary nie są skuteczne"124. Podstawowym czynnikiem wpływającym na skuteczność oddziaływania wychowawczego represji karno-administracyjnej miała być surowość

${ }^{121}$ Notatka MSW z sierpnia 1957 r. w sprawie opinii o projekcie ustawy uchylającej dekret z 4 marca 1953 r., IPN BUiAD MSW II 6438, s. 97.

122 A. Zawadzki, List do prokuratorów z okazji dziesięciolecia Prokuratury PRL, [w:] Prokuratura PRL $w$ dziesięcioleciu 1950-1960, red. I. Druski, Warszawa 1960, s. 1.

${ }^{123}$ H. Chmielewski, Praworządność nie jest pobłażliwością, „Poradnik dla Kolegiów Orzekających” 1957, nr 3, s. 2.

${ }_{124}$ H. Chmielewski, Jeszcze o brakach w pracy kolegiów, „Poradnik dla Kolegiów Orzekających” 1957, nr 6, s. 2. 
orzekanych kar, gdyż „aby kara była wychowawcza, musi być ona odpowiednio dolegliwa" 125 .

Obranie w drugiej połowie 1957 r. represyjnego kierunku polityki karno-administracyjnej skutkowało odrzuceniem „zbyt liberalnego” projektu Prawa Karno-Administracyjnego oraz utrzymaniem w mocy dekretu z 4 marca 1953 r. Przewidziana w nim zastępcza kara aresztu w pełni odpowiadała nowym założeniom stosowania represji karno-administracyjnej, fakt zaś występowania tej kary zaczęto traktować jako punkt wyjścia procesu stopniowego nasycania orzecznictwa karno-administracyjnego środkami penalnymi o charakterze izolacyjnym. Wobec braku większych sukcesów w zwalczaniu plagi społecznej chuligaństwa, w marcu 1958 r. uchwalono ustawę wzmacniającą represje za tego rodzaju czyny, istotnie zmieniając przy tym podstawowe założenia ustawy z 15 grudnia $1951 \mathrm{r}$. Ustawa z 22 maja 1958 r. o zaostrzeniu odpowiedzialności karnej za chuligaństwo $^{126}$ upoważniła kolegia do stosowania aresztu zasadniczego i zastępczego w sprawach o ściśle określone wykroczenia przeciwko porządkowi publicznemu.

Kolejnym krokiem w kierunku represyjnego ukształtowania polityki karno-administracyjnej była przeprowadzona w grudniu 1958 r. nowelizacja ustawy z 15 grudnia 1951 r. ${ }^{127}$ Nowelizacja rozszerzyła stosowanie kary aresztu zasadniczego na dalsze rodzaje wykroczeń, którym przypisywano charakter chuligański, oraz na te, do których znamion należała nietrzeźwość sprawcy. Nastąpiło całkowite zniesienie kary pracy poprawczej, skutkiem czego było wyposażenie kolegium w możliwość stosowania zastępczej kary aresztu w razie nieuiszczenia grzywny $\mathrm{w}$ wyznaczonym terminie ${ }^{128}$. W ten oto sposób zastępcza kara aresztu została podniesiona do rangi jednego z podstawowych środków penalnych orzecznictwa karno-administracyjnego. Nawiązując do wprowadzonych w 1955 r. zmian w trybie wykonywania tej kary, nowelizacja ustawy z 15 grudnia 1951 r. zakazywała stosowania kary aresztu zarówno zasadniczego, jak i zastępczego względem nieletnich oraz w stosunku do osób, których warunki osobiste uniemożliwiały odbycie tej kary ${ }^{129}$.

Wyraźnemu zaostrzeniu represyjności polityki karno-administracyjnej w początkowym okresie rządów Gomułki towarzyszyło wyznaczenie kolegiom nowych zadań, zgodnych z priorytetami polityki wewnętrznej władz. Pod koniec lat pięćdziesiątych uwaga komunistów koncentrowała się na zwalczaniu chuli-

125 J. Staniszewski, Wplyw zasad postępowania karno-administracyjnego na orzeczenie, „Poradnik dla Kolegiów Orzekających" 1957, nr 3, s. 23.

126 Dz. U. Nr 34, poz. 152.

127 Ustawa z 2 grudnia 1958 r. o zmianie ustawy z 15 grudnia 1951 r. o orzecznictwie karno-administracyjnym (Dz. U. Nr 77, poz. 396).

128 Ustawa - to jeszcze nie wszystko, „Poradnik dla Kolegiów Orzekających” 1958, nr 6, s. 3-4.

129 J. Jakubowska-Hara, Grzywna..., s. 49-50. 
gaństwa ${ }^{130}$ i alkoholizmu, zmierzano także do konfrontacji z Kościołem katolickim szybko odzyskującym swoje wpływy w społeczeństwie ${ }^{131}$. Sprawozdanie MSW z działalności kolegiów w 1959 r. zawierało najpierw ocenę orzecznictwa w sprawach o wykroczenia chuligańskie i alkoholowe, następnie omówienie zwalczania wykroczeń przeciwko bezpieczeństwu ruchu drogowego i w zakresie przestrzegania przepisów przeciwpożarowych. Podkreślono także prawidłową postawę kolegiów „w sprawach związanych z położeniem tamy masowemu łamaniu przepisów prawa przez kler i aktyw przykościelny"132. Dopiero na końcu tej wyliczanki znalazły się dostawy obowiązkowe, ale omówione łącznie $\mathrm{z}$ orzecznictwem karno-administracyjnym $\mathrm{w}$ sprawach spekulacji mięsem i jego przetworami. Według danych MSW w 1959 r. za niewykonanie dostaw obowiązkowych ukarano 18843 osoby, z czego 15 tysięcy w całości wykonało zaległe dostawy przed otrzymaniem wezwania do odbycia zastępczej kary aresztu ${ }^{133}$.

Widoczna jest tutaj cechująca okres gomułkowski tendencja drugoplanowego traktowania wykroczeń z dziedziny dostaw obowiązkowych na tle nowych zadań postawionych przed kolegiami $\mathrm{w}$ związku ze zmianą akcentów polityki wewnętrznej władz. Wbrew wyrażanym przez chłopów w 1956 r. nadziejom, ekipa Gomułki nie zdecydowała się na zniesienie dostaw obowiązkowych, ale rezygnując z programu kolektywizacji wsi zaczęła bardziej tolerancyjnie postrzegać rolnictwo indywidualne. Stąd do spraw o niewykonanie dostaw obowiązkowych kolegia podchodziły bardziej liberalnie, często kierując się nie tyle literą prawa, co względami życiowymi i społecznymi ${ }^{134}$. Kolegia otrzymywały coraz mniej wniosków o ukaranie chłopów zalegających z dostawami obowiązkowymi, gdyż zgodnie z zaleceniami MSW w latach sześćdziesiątych stopniowo rezygnowano ze stosowania środków represyjnych na rzecz administracyjnego postępowania przymusowego. Przeprowadzona w 1963 r. przez NIK kontrola orzecznictwa karno-administracyjnego stwierdziła szerokie stosowanie przepisów postępowania przymusowego $\mathrm{w}$ administracji $\mathrm{w}$ sprawach o niewykonywanie w terminie obowiązkowych dostaw płodów rolnych ${ }^{135}$. Sprawozdania

${ }_{130}$ Patrz M. Łysko, Problem chuligaństwa w orzecznictwie karno-administracyjnym Polski Ludowej, „Czasopismo Prawno-Historyczne” 2008, t. LX, z. 2

131 Patrz M. Łysko, Kolegia karno-administracyjne w walce $z$ Kościołem katolickim w Polsce (1956-1970), „Czasopismo Prawno-Historyczne” 2007, t. LIX, z. 1.

132 O sytuacji w orzecznictwie karno-administracyjnym w 1959 r., „Poradnik dla Kolegiów Orzekających" 1960, nr 2, s. 8-9.

133 Ibidem, s. 9.

$134 \mathrm{H}$. Wąsik, Uwagi na tle wyników badania orzecznictwa karno-administracyjnego „Biuletyn Generalnej Prokuratury" 1961, nr 2, s. 57-58.

135 W sprawozdaniu NIK zawarto wzmiankę, iż „wg danych MSW z terenu 5 województw około 120 tys. spraw o niewykonanie w terminie obowiązkowych dostaw załatwiono skutecznie w drodze przymusu administracyjnego". Sprawozdanie NIK z kontroli realizacji przepisów ustawy o orzecznictwie karno-administracyjnym, Archiwum Akt Nowych, zespół akt Ministerstwa Sprawiedliwości, sygn. teczki 1975, s. 6. 
z przebiegu orzecznictwa karno-administracyjnego pochodzące z drugiej połowy lat sześćdziesiątych nie poruszały już problematyki wykroczeń z dziedziny dostaw obowiązkowych ${ }^{136}$, która definitywnie zniknęła $\mathrm{z}$ kręgu zainteresowania kolegiów wraz ze zniesieniem przez Edwarda Gierka w 1971 r. obowiązku dostaw płodów rolnych ${ }^{137}$. Oznaczało to usunięcie przewidzianej dekretem z 4 marca 1953 r. zastępczej kary aresztu z katalogu środków penalnych orzecznictwa karno-administracyjnego ${ }^{138}$, co nastąpiło wraz z uchwaleniem w $1971 \mathrm{r}$. nowego kodeksu wykroczeń ${ }^{139}$.

\section{Wnioski}

Wprowadzenie w 1951 r. przez władze Polski Ludowej dostaw obowiązkowych płodów rolnych należy rozpatrywać nie tylko w kategoriach ekonomicznych, lecz także jako próbę realizacji założeń ideologicznych polityki gospodarczej komunistów. W myśl stalinowskiej teorii o zaostrzaniu się walki klasowej, w miarę postępów budownictwa socjalistycznego dostawy obowiązkowe traktowano w kategoriach instrumentu presji ekonomicznej wywieranej na bogatych chłopów, wprowadzając restrykcyjny system progresji wymiaru dostaw w zależności od wielkości gospodarstwa. Narastające problemy z realizacją planu dostaw obowiązkowych skutkowały stosowaniem przez komunistów metod represyjnych i kar finansowych względem rolników indywidualnych. Przekonanie, że za pomocą środków represyjnych można przezwyciężyć trudności gospodarcze, towarzyszyło władzy komunistycznej od początku jej istnienia, czego wyrazem były liczne akty prawne penalizujące zachowania, które w warunkach wolnego rynku poddawane są swobodnemu działaniu sił podaży i popytu. Stosowanie represji zamiast instrumentów wolnorynkowych w największym stopniu dotyczyło rolnictwa, o czym świadczy fakt wymierzenia w 1953 r. rolnikom indywidualnym około 250 tysięcy kar, przede wszystkim w trybie postępowania karno-administracyjnego ${ }^{140}$. Liczby te pokazują, jak dużą rolę w represjonowa-

136 Przykładowo sprawozdanie z działalności Departamentu Społeczno-Administracyjnego MSW w 1965 r. w punkcie dotyczącym orzecznictwa karno-administracyjnego nie zawierało żadnej wzmianki o represjonowaniu przez kolegia rolników niewykonujących dostaw obowiązkowych. Główne kierunku działalności Departamentu Społeczno-Administracyjnego MSW w 1965 r., IPN BU MSW II 7489, s. 284-285.

137 Ustawa z dnia 26 października 1971 r. o zniesieniu obowiązkowych dostaw zbóż, ziemniaków i zwierząt rzeźnych (Dz. U. Nr 27, poz. 253).

$138 \mathrm{Na}$ mocy art. IV ustawy z dnia 20 maja 1971 r. Przepisy wprowadzające Kodeks wykroczeń

(Dz. U. Nr 12, poz. 115).

139 Ustawa z dnia 20 maja 1971 r., Kodeks wykroczeń (Dz. U. Nr 12, poz. 114).

140 D. Jarosz, Polityka władz komunistycznych $w$ Polsce $w$ latach 1948-1956 a chłopi, Warszawa 1998, s. 501. 
niu chłopów odgrywały kolegia karno-administracyjne, które po wprowadzeniu w grudniu $1951 \mathrm{r}$. wychowawczej koncepcji orzecznictwa karno-administracyjnego zostały pozbawione możliwości stosowania środków karnych o charakterze izolacyjnym. Negatywne doświadczenia pierwszego roku funkcjonowania nowych rozwiązań, zwłaszcza powszechnie występujące problemy z egzekucją wymierzonych przez kolegia kar grzywny, skłoniły władze do rychłej rezygnacji $\mathrm{z}$ wychowawczej koncepcji orzecznictwa karno-administracyjnego w zakresie dostaw obowiązkowych. Celem ratowania zagrożonego planu dostaw zdecydowano się na wprowadzenie zastępczej kary aresztu, którą kolegia musiały uwzględnić w orzeczeniu o ukaraniu grzywną bez względu na okoliczności sprawy i warunki osobiste obwinionego. Kara ta posiadała charakter typowo represyjny, a towarzysząca jej perspektywa kilkumiesięcznego pobytu w areszcie skutecznie mobilizowała ukaranych chłopów do zapłacenia orzeczonej przez kolegium grzywny oraz wyrównania zaległości w dostawach. Poprawa stanu wykonania dostaw obowiązkowych zepchnęła na dalszy plan problem właściwego stosowania zastępczej kary aresztu, co prowadziło do wielu wypaczeń i krzywd wyrządzonych ludności wiejskiej. Nie można jednak przypisywać kolegiom karno-administracyjnym wyłącznej winy za taki stan rzeczy, gdyż wydawały one orzeczenia na podstawie wniosków o ukaranie sporządzonych przez powiatowych pełnomocników aparatu skupu, który funkcjonował na zasadzie „akcyjności działania". Wnioski o ukaranie były masowo kierowane do kolegiów dopiero wtedy, gdy załamywał się plan skupu na danym terenie, a władze zwierzchnie żądały szybkiego przywrócenia dyscypliny wykonania dostaw. Naprędce sporządzane, bez uwzględnienia warunków osobistych i możliwości ekonomicznych obwinionego, wnioski o ukaranie, prowadziły do mechanicznego stosowania represji karno-administracyjnej przez obarczone dużą ilością spraw kolegia.

Wraz z pojawieniem się symptomów „odwilży” zmniejsza się represyjność polityki karno-administracyjnej, gdyż władze stopniowo wycofują się z traktowania dostaw obowiązkowych w kategoriach „walki klasowej”. Wyrazem rezygnacji z metod represyjnych było postrzeganie zastępczej kary aresztu w kategoriach środka oddziaływania wychowawczego, ostrzejszego w swojej wymowie od rozmów z chłopami i kary grzywny. Prowadziło to do sprzecznej z prawem, ale usprawiedliwionej względami życiowymi praktyki, polegającej na odstąpieniu od wykonania kary aresztu w razie wyrównania zaległości w dostawach przez ukaranego lub rodzinę chłopa osadzonego w areszcie. Praktyce tej towarzyszyła coraz głośniejsza krytyka rygorystycznego trybu stosowania tej kary, połączona z postulatami wprowadzenia możliwości odstąpienia kolegium od ustalania aresztu zastępczego ze względu na sytuację osobistą i ekonomiczną ukaranego. Uwzględniającą te żądania nowelizację dekretu z 4 marca 1953 r. należy ocenić jako krok naprzód w kierunku łagodzenia represyjności polityki karno-administracyjnej w sprawach o dostawy obowiązkowe. Wagę tego kroku pomniejsza przyznanie kolegiom prawa odstąpienia od ustalania aresztu zastępczego jedy- 
nie w ściśle określonych przypadkach, zamiast fakultatywnego stosowania tej kary. Praktyczne znaczenie zastępczej kary aresztu było coraz mniejsze, do czego przyczyniła się zmiana podejścia władz do zagadnienia dostaw obowiązkowych w przełomowym $1956 \mathrm{r}$. Na fali przemian społeczno-politycznych pojawiły się postulaty likwidacji zastępczej kary aresztu, a nawet całkowitej rezygnacji ze stosowania represji karno-administracyjnej w sprawach o dostawy obowiązkowe. Słusznie wskazywano, że kolegia zamiast wywierać presję ekonomiczną na zalegających z dostawami chłopach, powinny skupić się na zwalczaniu rzeczywistych problemów społecznych, takich jak plaga chuligaństwa i alkoholizmu. W tym miejscu należałoby zadać pytanie o zasadność wprowadzenia kary aresztu jedynie w sprawach o niewykonanie dostaw obowiązkowych, podczas gdy $\mathrm{w}$ przypadku znacznie poważniejszych z punktu widzenia szkodliwości społecznej wykroczeń chuligańskich i tzw. „alkoholowych” kolegia mogły stosować zupełnie nieprzydatną w praktyce karę pracy poprawczej. Należy przypuszczać, że gdyby w 1953 r. zdecydowano się na wprowadzenie zastępczej kary aresztu $\mathrm{w}$ ważniejszych $\mathrm{z}$ punktu widzenia porządku publicznego sprawach o wykroczenia chuligańskie, to chuligaństwo nie rozwinęłoby się do rozmiarów ważnego problemu społecznego.

Zmiana założeń polityki karno-administracyjnej w pożądanym społecznie kierunku nastąpiła już w pierwszym okresie rządów Gomułki, który jako zwolennik rządów twardej ręki zdecydowanie opowiadał się za zaostrzeniem represyjności stosowanych przez kolegia środków karnych. Rok 1958 przynosi wyraźne odejście od wychowawczych założeń orzecznictwa karno-administracyjnego na rzecz wprowadzenia kary aresztu, zarówno w postaci kary zasadniczej, jak też zastępczej na wypadek nieuiszczenia grzywny. Takie rozwiązanie oznaczało utrzymanie w mocy zastępczej kary aresztu w sprawach o dostawy obowiązkowe, jednak wobec zmiany priorytetów polityki wewnętrznej władz kara ta odgrywała coraz mniejszą rolę. Wynikało to z faktu, że towarzysz „Wiesław” potrafił zdobyć się na w miarę realistyczne postrzeganie problematyki rolnictwa $\mathrm{w}$ kategoriach ekonomicznych. W celu poprawy efektywności gospodarki rolnej po 1956 r. częściowo ograniczono zakres dostaw obowiązkowych na rzecz korzystnie cenowo zmodyfikowanej kontraktacji, zmniejszono także stawki podatku gruntowego i jego pochodne ${ }^{141}$. Kryzys społeczno-polityczny 1970 r. wpłynął na zmianę strategii zaopatrzenia w produkty rolne, w ramach której nie przewidziano już dostaw obowiązkowych. Zniesieniu przez ekipę Gierka w 1971 r. dostaw obowiązkowych towarzyszyła reforma systemu skupu i kontraktacji oraz podniesienie cen na niektóre produkty. W orzecznictwie karno-administracyjnym oznaczało to eliminację przewidzianej dekretem z 4 marca 1953 r. zastępczej kary aresztu z katalogu środków karnych stosowanych przez kolegia.

141 A. Machnikowska, Polityka finansowa..., s. 576. 